\title{
Point Mutations Associated with HIV-1 Drug Resistance, Evasion of the Immune Response and AIDS Pathogenesis
}

\author{
Makobetsa Khati1,2 and Laura Millroy ${ }^{1}$ \\ ${ }^{1}$ Council for Scientific and Industrial Research, Biosciences, \\ ${ }^{2}$ Department of Medicine, \\ Groote Schuur Hospital and University of Cape Town, Cape Town, \\ South Africa
}

\section{Introduction}

Point mutations within the human immunodeficiency virus-type 1 (HIV-1) genome confer resistance to antiretroviral drugs. The mutations also help the virus to evade the immune system response and influence transmission and progression of the disease, collectively called acquired immune deficiency syndrome (AIDS) pathogenesis. This chapter presents an up-to-date critical review of the literature and provides a synthesis of the current understanding of HIV-1 point mutations in relation to drug resistance, evasion of the immune system and AIDS pathogenesis. First, to prime the reader, the chapter briefly describes organization and function of the HIV-1 genes. It then pinpoints salient point mutations within specific HIV-1 genes associated with resistance to current antiretroviral drugs. In particular, it pays attention to the env gene and its product, the surface envelope (Env) glycoprotein because the Env protein mediates viral entry, tropism and disease progression. Thus the role and frequencies of point mutations within the env gene is related to HIV-1 transmission dynamics and progression to AIDS. The env gene and Env protein are further unpacked to provide a better understanding of the role point mutations within this gene play in helping the virus to evade antibody mediated immune response. Finally, drawing mainly from our recent research work, the chapter proposes an aptamer-based strategy for the design of desirable approaches that can help circumvent HIV-1 point mutations and delay or diminish drug resistance.

\section{Organization and function of the HIV-1 genes}

The genome of HIV-1, unlike other retroviruses is made up of a single coding RNA strand of $9.2 \mathrm{~kb}$ in length and is far more complex than those of other retroviruses. The genome of most retroviruses is diploid. It is made up of two identical RNA strands with a plus (+) polarity. All retroviruses have the env, gag and pol genes, but HIV-1 has 6 additional regulatory and accessory genes (Figure 1), which produces 14 proteins (Table 1). The env gene encodes the envelope (Env) protein. The Env protein is made up of two polypeptides derived from a gp160 single precursor; the transmembrane (TM) gp41 and the outer surface 


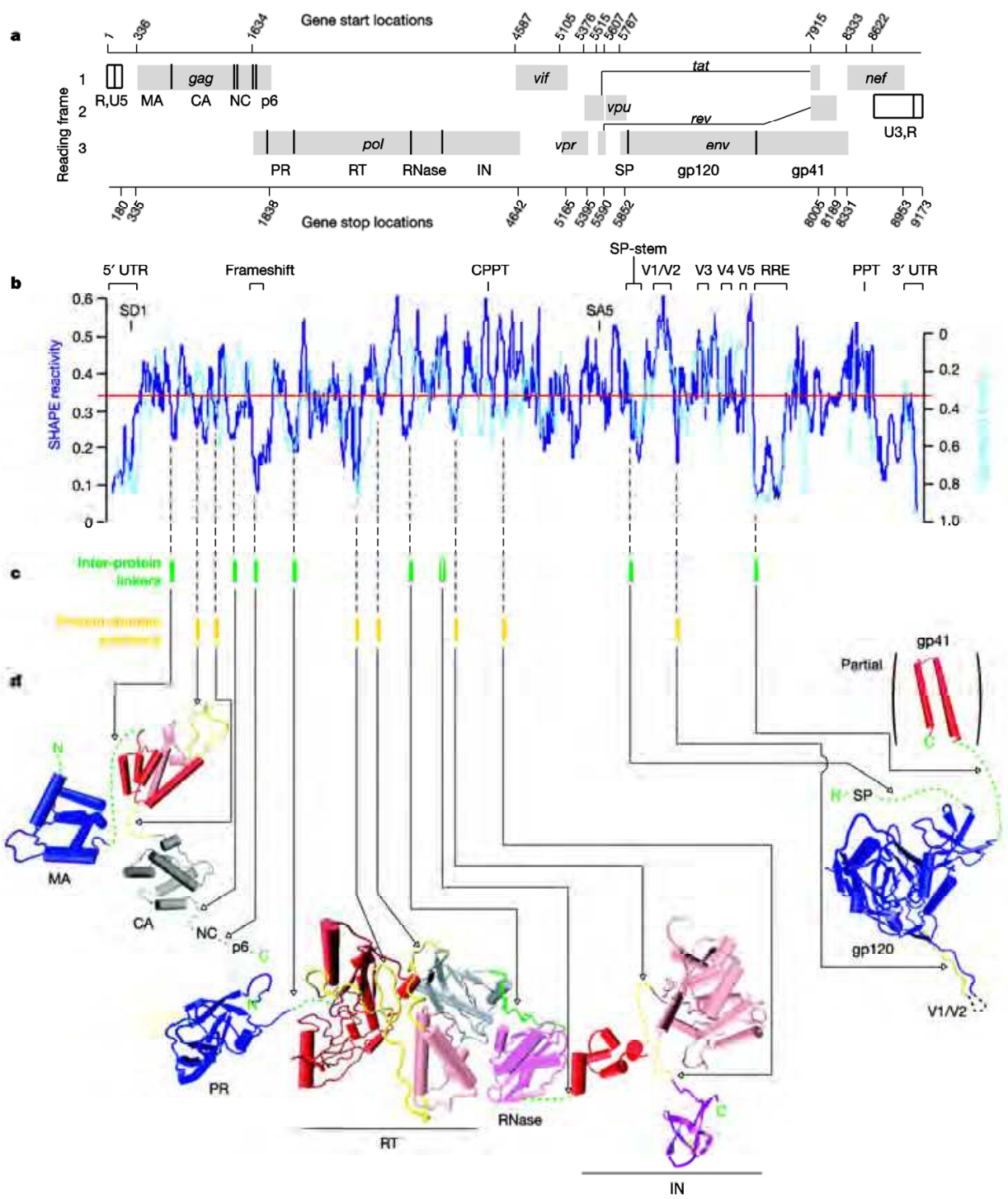

Fig. 1. Organization and function of the HIV-1 genome in relation to the proteins coded. (a) Protein coding region are shown as grey boxes. (b) Comparison of the pairing probability of nucleotides in the overall HIV-1 structure using 2'-hydroxyl acylation analysed by primer extension (SHAPE) reactivity. (c) Inter-protein linkers and unstructured peptide loops that link protein domains. (d) Three-dimensional structures of large and key HIV-1 proteins encoded by env and pol genes, respectively. Reproduced from (Watts et al., 2009) with permission from Nature Publishing Group (Copyright Clearance Centre License Number: 2754150202433) 
(SU) gp120 (Figure 1). For a mature virion, on the inner leaflet of the envelope there are proteolytically processed gag gene products: a p17 matrix (MA) protein and a p24 capsid (CA) protein that form the core of the particle and an RNA-binding p7 nucleocapsid (NC) protein (Figure 1 and Table 1). Other proteins present in the core of the virion particle are derived from the pol gene and perform enzymatic functions. HIV-1 gp120 and gp41 (env gene products) and pol gene products, reverse transcriptase (RT) and integrase (IN) are involved in early stages of the HIV life cycle and are primary targets of therapeutic drugs. Env, RT and IN are targets of antiretroviral drugs called entry inhibitors (EI), reverse transcriptase inhibitors (RTI) and integrase inhibitors (INI), respectively. Another pol gene product called protease (PR) is involved in later stages of the HIV life cycle and it is also a target of a class of antiretroviral drugs called protease inhibitors. Other HIV-1 genes encode auxiliary proteins (Figure 1).

\begin{tabular}{|c|c|c|}
\hline Gene & Protein encoded & Function \\
\hline gag & Gag MA & $\begin{array}{l}\text { Membrane anchoring; env interaction; nuclear } \\
\text { transport of viral core }\end{array}$ \\
\hline gag & Gag CA & Core capsid \\
\hline gag & Gag NC & Binds RNA and Vpr, respectively \\
\hline pol & Protease (PR) & gag/pol cleavage \\
\hline pol & Reverse Transcriptase (RT) & Reverse transcription \\
\hline pol & RNase H & RNase $H$ activity \\
\hline pol & Integrase (IN) & DNA provirus integration \\
\hline env & Env (gp120 and gp41) & $\begin{array}{l}\text { gp120 binds CD4 receptor and CXCR4/CCR5 } \\
\text { co-receptors, gp } 41 \text { mediates fusion }\end{array}$ \\
\hline tat & Tat & Viral transcription activator \\
\hline rev & $\operatorname{Rev}$ & $\begin{array}{l}\text { RNA transport, stability and utilization factor } \\
\text { (phosphoprotein) }\end{array}$ \\
\hline vif & Vif & Promotes virion maturation and infectivity \\
\hline vpr & Vpr & $\begin{array}{l}\text { Promotes nuclear localization of } \\
\text { preintegration complex, inhibits cell division, } \\
\text { arrest infected cells at } \mathrm{G} 2 / \mathrm{M}\end{array}$ \\
\hline vpu & Vpu & $\begin{array}{l}\text { Promotes extracellular release of viral } \\
\text { particles. Important for viral assembly and } \\
\text { budding }\end{array}$ \\
\hline$n e f$ & Nef & CD4 and class I downregulation \\
\hline
\end{tabular}

Table 1. HIV-1 genes, proteins coded by the respective genes and their functions

\section{Point mutations and HIV-1 drug resistance}

Antiretroviral drugs are currently the cornerstone of controlling HIV-1 in infected individuals. To date, 24 antiretroviral drugs have been approved and licensed for the treatment of HIV-1 infection. Thirteen of these drugs are reverse transcriptase inhibitors (nine nucleoside and four non-nucleoside RT inhibitors); nine are protease inhibitors; a fusion inhibitor; a CCR5 inhibitor and an integrase inhibitor. However, despite the use of 
current antiretroviral drugs, HIV-1 can still persists in infected individuals by accumulating mutations, which make it resistant to one or more drugs. The antiretroviral drug resistant mutations can be identified by one or more of the following: (a) in vitro passage experiments or site directed mutagenesis studies (Clark et al., 2006); (b) mutagenically separated PCR (Frater et al., 2001); (c) drug susceptibility testing (Petropoulos et al., 2000; Svicher et al., 2011); (d) nucleotide sequencing of viruses from patients failing a specific drug (McNicholas et al., 2011; Shulman et al., 2004); (e) correlation studies between genotype at baseline and virologic response in patients exposed to a specific antiretroviral drug (Demeter et al., 2008). Currently, more than 200 mutations in the HIV-1 pol and env genes associated with resistance to current antiretroviral drugs, which include reverse transcriptase inhibitors (RTIs), protease inhibitors (PIs), integrase inhibitors (INI), fusion inhibitors and attachment inhibitors respectively, have been identified (V. A. Johnson et al., 2010; Shafer \& Schapiro, 2008).

\subsection{Point mutations associated with resistance to NRTIs}

HIV-1 RT is a heterodimer made up of two subunits, p66 and p51 (di Marzo Veronese et al., 1986) and its crystal structure has been solved (Arnold et al., 1992; Kohlstaedt et al., 1992b). RT is important in the HIV-1 life cycle because it orchestrates synthesis of a linear doublestranded DNA copy of a viral single-stranded RNA genome. The knowledge that HIV-1 is a retrovirus immediately pinpointed RT synthesis of proviral DNA as a target for a class of antiretroviral drugs called RTIs. Indeed, RTIs including the prototype azidothymidine (AZT) also known as zidovudine (ZDV), were the first to be approved for clinical use (Fischl et al., 1987), and remains the mainstay of HIV-1 therapy. Nearly half of current antiretroviral drugs target the polymerase activity of RT. RTIs belong to one of the two broad categories: nucleoside RT inhibitors (NRTIs) and non-nucleoside RT inhibitors (NNRTIs).

NRTIs are structural analogues of natural substrate of DNA synthesis. They lack the 3'hydroxyl group $\left(3^{\prime}-\mathrm{OH}\right)$ and hence they block HIV-1 replication by acting as chain terminators when incorporated into a viral DNA by RT. Two basic NRTI resistance mechanisms are exclusion and excision. The exclusion mechanism involves enhanced discrimination at the time the NRTI tri-phosphate is incorporated in the nascent DNA strand. The M184V/I point mutation (Figure 2 and Table 2), which selectively reduces incorporation of abacavir (ABC); emtricitabine (FTC) and lamivudine (3TC) NRTIs into a nascent DNA chain by steric hindrance (Gao et al., 2000; Sarafianos et al., 1999) is a common example of the exclusion mechanism. M184V point mutation causes a median 1.5-fold and 3.0-fold reduction in susceptibility to didanosine (ddI) and $\mathrm{ABC}$, respectively in the PhenoSenseGT ${ }^{\mathrm{TM}}$ assay (Petropoulos et al., 2000; Rhee et al., 2004). However several clinical trials have shown that $\mathrm{ABC}$ and ddI retain clinical activity in the presence of M184V point mutation (Brun-Vezinet et al., 2003; J. J. Eron, Jr. et al., 2007; Lanier et al., 2004a; Marcelin et al., 2005; Molina et al., 2005; M. A. Winters et al., 2003). The phenotypic and clinical significance of $\mathrm{M} 184 \mathrm{~V}$ is influenced by the presence or absence of other NRTI resistance mutations (Shafer \& Schapiro, 2008). For instance, the presence of K65R or L74V (J. Eron, Jr. et al., 2006; Gallant et al., 2006; Moyle et al., 2005) point mutations (Figure 2 and Table 2) in addition to the M184V is sufficient for high level resistance to ddI and ABC (Rhee et al., 2004), particularly in patients with non-subtype B clades (Harrigan et al., 2000; Lanier et al., 2004a; Svarovskaia et al., 2007; M. A. Winters et al., 1997). K65R has emerged more rapidly during the in vitro passage of subtype $\mathrm{C}$ compared with subtype B isolates in the presence of 
increasing concentrations of TDF (Brenner et al., 2006). The emergence of K65R mutation is suppressed maximally in regimens containing AZT compared with d4T (Roge et al., 2003). Thus, the K65R point mutation commonly causes intermediate resistance to tenofovir (TDF), ABC, ddI, 3TC and FTC (Table 2), low level resistance to d4T, and increased susceptibility to AZT (Antinori et al., 2007; Lanier et al., 2004b). There is a body of evidence suggesting that K65R mutation occurs more commonly in low-income countries when patients with nonsubtype B HIV-1 strains are treated with d4T/ddI and d4T/3TC (Doualla-Bell et al., 2006; Hawkins et al., 2009) or TDF/3TC (Rey et al., 2009). In comparison to K65R, L74V point mutation causes intermediate resistance to ddI and $A B C$, and a slight increase in susceptibility to AZT and TDF (Rhee et al., 2006b). L74V and K65R mutations rarely occur in the same viruses (Shafer \& Schapiro, 2008). However, several patients harbouring HIV-1 species containing the $\mathrm{L} 74 \mathrm{~V}$ point mutation while receiving a regimen containing $\mathrm{ABC}$ or ddI have been found to have minor variants containing K65R (Descamps et al., 2006; Svarovskaia et al., 2007). On the other hand, K65R and M184V mutations are primarily found in patients receiving the NRTI backbone TDF/3TC (Gallant et al., 2004; Margot et al., 2006) and less commonly ABC/3TC (Moyle et al., 2005) or TDF/FTC (Gallant et al., 2006; Smith et al., 2008). L74V and M184V mutations primarily occur in patients receiving ABC/3TC or ddI/3TC/FTC NRTI backbones (Descamps et al., 2006; Moyle et al., 2005; Sosa et al., 2005). In addition to the M184V, K65R and L74V mutations, which between them cause resistance to $\mathrm{ABC}, 3 \mathrm{TC}, \mathrm{FTC}, \mathrm{TDF}$ and ddI by the exclusion mechanism; there is a complex set of several mutations that involves Q151M causing multi-NRTI resistant (Figure 2 and Table 2). All of the amino acids involved in the NRTIs resistance by the exclusion mechanism are in the fingers or the palm of RT (Figure 2) and could potentially affect the binding of an incoming deoxy-nucleotide triphosphate (dNTP).

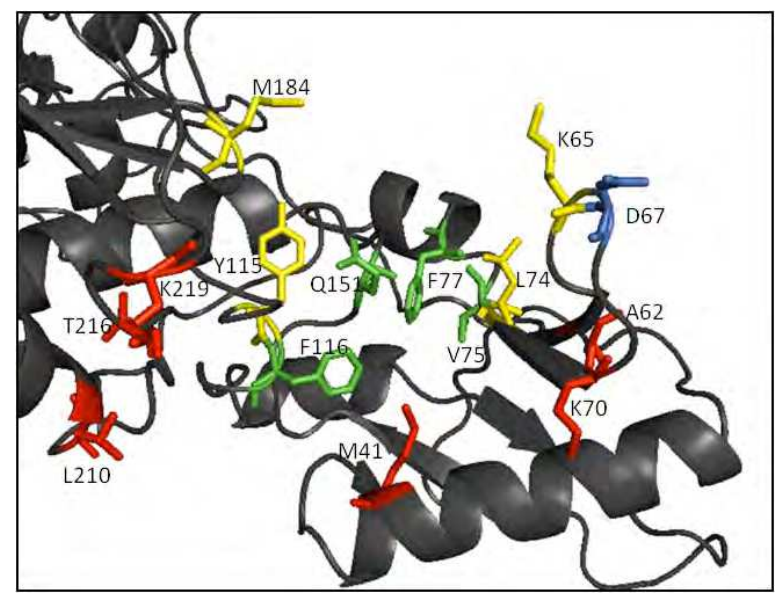

Fig. 2. Ribbon representation of the NRTI-binding site (palm and fingers of RT) showing residues that confer resistant when mutated as illustrated in Table 2. Red show amino acid residues that confer multi-NRTI resistance (all the FDA approved drugs). Green show residues that affect all the FDA approved NRTIs except for TDF. Mutations of blue residues are associated with TAMs. Yellow shows residues that confer resistance to certain NRTIs (Table 2) by the exclusion mechanism. 


\begin{tabular}{|c|c|c|c|c|c|c|c|c|c|c|c|c|c|c|c|c|c|c|c|c|c|c|c|c|}
\hline NRTI & \multicolumn{4}{|c|}{ TAMs (excision) } & \multicolumn{3}{c|}{ Non-TAMs (exclusion) } & \multicolumn{3}{c|}{ Multi-NRTI resistance mutations } \\
\hline * & M41 & D67 & K70 & I210 & T215 & K219 & K65 & K70 & L74 & V75 & Y115 & M184 & T69 & Q151 & A62 & V75 & F77 & F116 \\
\hline 3TC & - & - & - & - & - & - & RN & EG & - & - & - & VI & Ins & M & V & - & - \\
\hline ABC & L & N & - & W & FY & - & RN & EG & VI & TM & F & VI & Ins & M & V & I & L & Y \\
\hline D4T & L & N & R & W & FY & QE & RN & - & - & TM & - & - & Ins & M & V & I & L & Y \\
\hline ddI & L & N & - & W & FY & - & RN & EG & - & TM & - & VI & Ins & M & V & I & L & Y \\
\hline FTC & - & - & - & - & - & - & RN & EG & - & - & - & VI & Ins & M & V & - & - & - \\
\hline TDF & L & N & & W & FY & - & RN & EG & - & M & F & - & Ins & M & V & - & - \\
\hline ZDV & L & N & R & W & FY & QE & - & - & - & - & - & - & Ins & M & V & I & L & Y \\
\hline
\end{tabular}

*Denotes position of consensus amino acids that confer resistance to NRTIs when mutated. Dashes (-) indicate that the respective NNRTIs are not affected by the mutation(s). All amino acids are denoted by the single letter annotation, except for "Ins", which stands for one or more amino acid insertions. Mutations in bold are associated with high levels of phenotypic resistance or reduced virologic

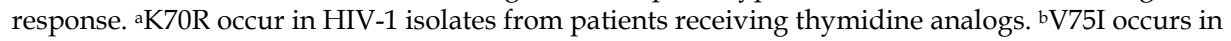
combination with Q151M. Modified from (Shafer \& Schapiro, 2008).

Table 2. Mutations in the RT gene associated with resistance to NRTIs

In contrast to the exclusion mechanism discussed above; the excision mechanism involves selective removal of the NRTI from the end of the viral DNA after it has been incorporated by RT (Arion et al., 1998; Boyer et al., 2001; Meyer et al., 1999; Meyer et al., 1998). This is ATPdependent excision and polymerization run in reverse, where an AZT resistant RT efficiently incorporates AZT triphosphate but has the enhanced ability to remove the incorporated AZT-monophosphate from the 5'-end of the template strand (Arion et al., 1998; Meyer et al., 1998). The first and well studied example of excision mechanism involves a set of AZT resistant mutations such as M41L, D67N, K70R, L210W, T215F/Y and K219E (Figure 1 and Table 1). These AZT resistant mutations are also called thymidine-analog mutations (TAMs) or excision-enhancing mutations (EEMs). In addition to AZT, the TAMs decrease susceptibility to $\mathrm{d} 4 \mathrm{~T}$ and to a lesser extent ABC, ddI and TDF (Whitcomb et al., 2003). TAMs are common in low income countries in which the fixed-dose combinations containing thymidine analogues are the mainstay of therapy (Ross et al., 2001). TAMs are also common in HIV-1 isolates from patients who began therapy in the pre-highly active antiretroviral therapy (HAART) era (De Luca et al., 2006; Rhee et al., 2005). The mutations accumulate in two distinct but overlapping patterns (De Luca et al., 2006; Gonzales et al., 2003; Marcelin et al., 2004b; Yahi et al., 1999). The type I pattern includes the M41L, L210W and T15Y mutations, respectively (De Luca et al., 2006; Miller et al., 2004). Type II patterns includes D67N, K70R, T215F and K219Q/E (Figure 2). D67N point mutation also occurs commonly with type I TAMs (Cozzi-Lepri et al., 2005; Rhee et al., 2007). However, K70R and L210W rarely occur together (Yahi et al., 2000). Type I TAMs cause higher levels of phenotypic and clinical resistance to the thymidine analogs and cross resistance to ABC, ddI and TDF than do the type II TAMs (Cozzi-Lepri et al., 2005; De Luca et al., 2007; Lanier et al., 2004a; Miller et al., 2004). The clinical significance of the type II TAMs is not well understood.

\subsection{Point mutations associated with resistance to NNRTIs}

The NNRTIs block RT activity allosterically by binding to a hydrophobic pocket close to but not contiguous with the polymerase active site (Figure 3). The NNRTI-binding pocket 
(NNIBP), which exists only in bound RT (Kohlstaedt et al., 1992a; Ren et al., 1995a), consists of the following amino acid residues: L100; K101; K013; V106; T107; V108; V179, Y181; Y188; V189; G190; F227; W229; L234; Y318 and E138 (Figure 3). Nearly all the of the NNRTI resistance mutations are within the NNIBP or adjacent to residues in the pocket (Ren et al., 2008; Ren \& Stammers, 2008; Sarafianos et al., 2004). The NNRTI resistant mutations are broadly classified as: (a) primary mutations that cause high-level resistance to one or more NNRTIs and are the first to develop during the therapy; (b) secondary mutations that usually occur in combination with primary NNRTI resistance mutations (c) minor nonpolymorphic mutations that may occur alone or in combination with other NNRTI resistance mutations and (d) polymorphic accessory mutations that modulate the effects of other NNRTI resistance mutations (Shafer \& Schapiro, 2008). There is low genetic barrier to NNRTI resistance. Only one or two mutations are required for high level resistance.

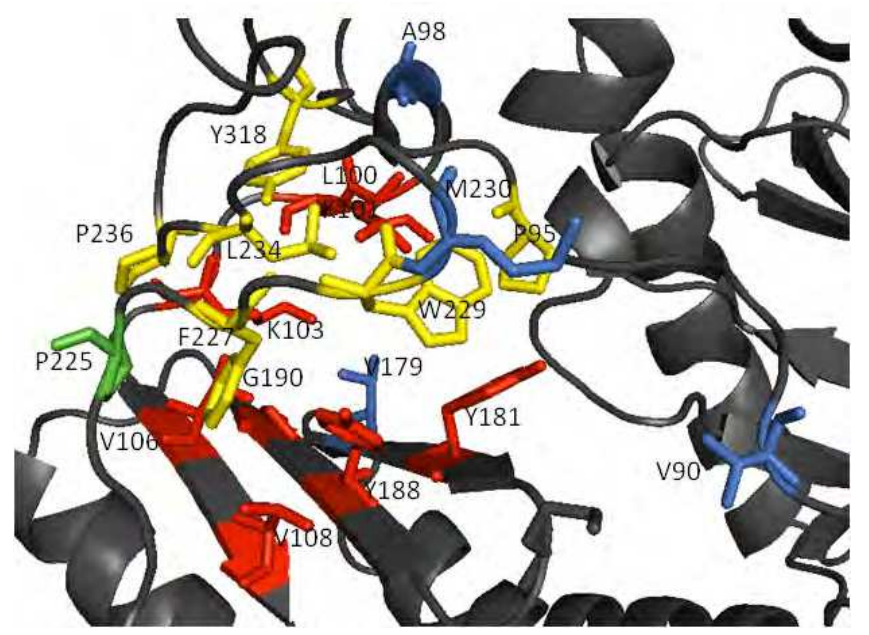

Fig. 3. Ribbon representation of the NNIBP showing the residues where NNRTI-resistance mutations occur. Red shows residues where primary point mutations which cause resistance to nearly all the current NNRTIs occur. Green shows a residue where a major secondary mutation which causes resistance to EFV occurs. Blue shows unique residues which confers resistance to ETR when mutated. Yellow shows residues where miscellaneous mutations that cause resistance to at least one of the NNRTI may occur.

The most frequently observed primary point mutations in patients treated with approved NNRTIs are K103N and Y181C (Table 3). Each of the primary NNRTI resistance mutations, namely, K103N/S; V106A/M; Y181C/I/V, Y188L/C/H and G190A/S/E (Figure 3 and Table 3) cause high level resistance to nevirapine (NVP) and variable resistance to efavirenz (EFV), ranging from about 2-fold for V106A and Y181C; 6-fold for G190A; 20-fold for K103N; and more than 50-fold for Y188L and G190S (Bacheler et al., 2001; Rhee et al., 2006b). Transient virologic responses to EFV-based salvage therapy regimen occur in some NNRTIexperienced patients but a sustained response is not common (Antinori et al., 2002; Delaugerre et al., 2001; Shulman et al., 2000; Walmsley et al., 2001). On the other hand, patients with any of the NNRTI resistance primary point mutations (Figure 3 and Table 3 ) 
may benefit from etravirine (ETR) salvage therapy (Lazzarin et al., 2007; Madruga et al., 2007). However, point mutations at Y181 and to a lesser extent G190 compromise ETR response and may provide the foundation for the development of high-level ETR resistance (Lazzarin et al., 2007; Madruga et al., 2007). Major secondary and minor/miscellaneous mutations that usually occur in combination with one of the primary NNRTI resistance point mutations are depicted in Figure 3 and their respective effects on NNRTIs is summarized in Table 3.

Current understanding suggests that there are at least three classes of NNRTI-resistance mechanisms (Sarafianos et al., 2009). The first mechanism involves loss or change of key hydrophobic amino acid residues in the NNIBP such as Y181, Y188 and F227 (Figure 3). Specific point mutations in one of these hydrophobic residues cause significant resistance through the loss of the aromatic ring interactions with NNRTIs (Das et al., 1996; Kohlstaedt et al., 1992a; Ren et al., 1995b; Ren et al., 2001; Ren et al., 2004). This causes high levels of resistance to the first generation NNRTIs, which are relatively rigid (Sarafianos et al., 2009). Second generation and more advanced NNRTI are designed with an inherent flexibility. This intrinsic flexibility called the wiggling and jiggling makes the second and subsequent generation NNRTIs to have compensatory interactions with RT that has mutations causing resistance to first generation NNRTIs (Das et al., 2008; Das et al., 2004). The second mechanism of NNRTI-resistance point mutations involves steric hindrance by amino acid residues in the central region of the NNIBP such as L100 and G190 (Figure 3). The L100I point mutation confers high-level resistance to all the current NNRTIs (Table 3) by changing the shape of the pocket (Ren et al., 2004). In contrast G190A point mutation, which also confers high-level resistance to almost all the current NNRTIs (Table 3), causes a bulge (Sarafianos et al., 2004). The third and last mechanism of NNRTI-resistance point mutation involves pocket entrance mutations at the rim of the NNIBP such as K103N and K101E (Figure 3). These point mutations cause resistance to first generation NNRTIs by interfering with the entry of NNRTIs into the NNIBP pocket (Hsiou et al., 2001; Ren et al., 2007). Second generation NNRTIs were designed to circumvent this problem. For instance, diarylpyrimidine NNRTIs such as ETR are able to inhibit HIV-1 isolates with K103N point mutation because they interact with the side chain of the mutated N103 residue (Das et al., 2004; Janssen et al., 2005).

\begin{tabular}{|c|c|c|c|c|c|c|c|c|c|c|c|c|c|c|c|c|}
\hline NRTI & \multicolumn{3}{|c}{ Primary mutations } & \multicolumn{4}{c}{$\begin{array}{c}\text { Major secondary } \\
\text { mutations }\end{array}$} & \multicolumn{3}{c|}{$\begin{array}{c}\text { Minor and miscellaneous } \\
\text { mutations }\end{array}$} \\
\hline * & K103 & V106 & Y181 & Y188 & G190 & L100 & K101 & P225 & F227 & M230 & A98 & V108 & V179 & P236 & K238 \\
\hline DLV & NS & AM & CIV & LHC & E & I & EP & - & C & L & G & I & DEF & L & NT \\
\hline EFV & NS & AM & CIV & LHC & ASE & I & EP & H & C & L & G & I & DEF & - & NT \\
\hline ETR & - & - & CIV & LHC & ASE & I & EP & - & C & L & G & - & DEF & - & - \\
\hline NVP & NS & AM & CIV & LHC & ASE & I & EP & - & LC & L & G & I & DEF & - & NT \\
\hline
\end{tabular}

*Denotes position of consensus amino acids that confer resistance to NNRTIs when mutated. Dashes (-) indicate that the respective NNRTIs are not affected by the mutation(s). All amino acids are denoted by the single letter annotation. Mutations in bold are associated with high levels of phenotypic resistance or reduced virologic response. Modified from (Shafer \& Schapiro, 2008).

Table 3. Mutations in the RT gene associated with resistance to NNRTIs 


\subsection{Point mutations associated with resistance to protease inhibitors}

Resistance mutations in the protease genes are classified as major or minor (V. A. Johnson et al., 2010). Major mutations are defined as those selected first in the presence of the protease inhibitor (PI) antiretroviral drug or those substantially reducing drug susceptibility. These mutations tend to be the primary contact residues for drug binding (Figure 4). Major PI resistance mutations that are of the most clinical significance occur at 17 largely nonpolymorphic positions (Figure 4). Mutations at 13 of these 17 positions, including mutations at the substrate cleft positions L23, D30, V32, I47, G48, I50, V82 and I84; the flap positions M46 and I54; and the interior enzyme positions L76, N88 and L90 (Figure 4), reduce susceptibility to at least one PI (Table 4). Mutations at the other 4 positions (L24, L33, F53 and G73) are also important because they are common, non-polymorphic and cause resistance to several PI (Rhee et al., 2006b).

Many major mutations reduce susceptibility to nelfinavir. In particular, L31I, D30N, M46I/L, G48V/M, I84V, N88D/S and L90M mutations are associated with high levels of phenotypic resistance to nelfinavir because they cause inferior virologic response to therapy relative to that obtainable with most other PI (Johnston et al., 2004; Patick et al., 1996; Vray et al., 2003; B. Winters et al., 2008). Similarly; I50L, I84 and N88S mutations are associated with high levels of phenotypic resistance to atazanavir/r (Colonno et al., 2004; Pellegrin et al., 2006; Rhee et al., 2006b; Vermeiren et al., 2007; Vora et al., 2006; B. Winters et al., 2008). $\mathrm{G} 48 \mathrm{~V} / \mathrm{M}, 184 \mathrm{~V}$ and $\mathrm{L} 90 \mathrm{M}$ mutations are relative contraindications to the use of saquinavir/r (Marcelin et al., 2004a; Marcelin et al., 2007; Zolopa et al., 1999). V32I, I47V/A, $\mathrm{I} 54 \mathrm{~L} / \mathrm{M}$ and $\mathrm{I} 84 \mathrm{~V}$ mutations are relative contraindications to the use of fosamprenavir/ $\mathrm{r}$ (Dandache et al., 2007; Masquelier et al., 2008; Pellegrin et al., 2007; B. Winters et al., 2008). $\mathrm{V} 82 \mathrm{~A} / \mathrm{F} / \mathrm{T}$ and $\mathrm{I} 84 \mathrm{~V}$ mutations are relative contraindications to the use of indinavir/ $\mathrm{r}$ (Table 4). V47A and V82L/T major mutations are relative contraindications to the use of lopinavir/r (Dandache et al., 2007; Friend et al., 2004; Kagan et al., 2005) and tipranavir/r (Baxter et al., 2006). Table 4 lists the 17 major PI resistance mutations that are of clinical significance.
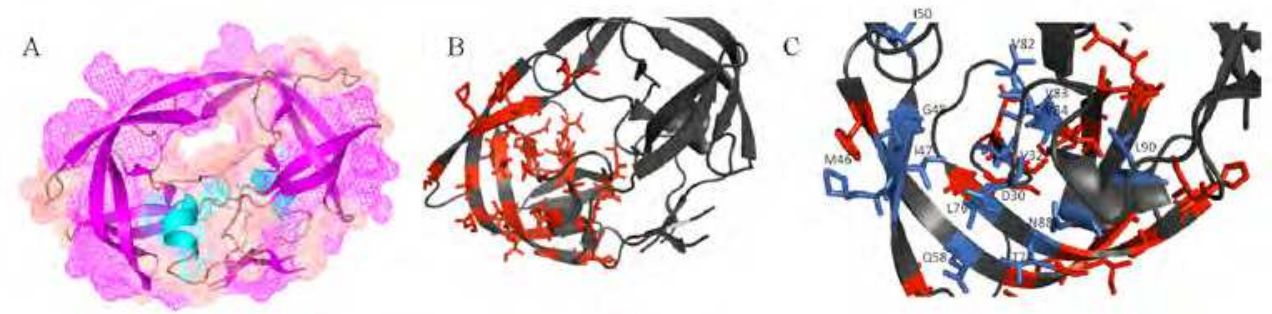

Fig. 4. Bound crystal structure of HIV-1 protease showing the residues where major PIresistance mutations occur. (A) Mesh illustration of HIV-1 protease in bound state with saquinavir. (B) Illustration of amino acid residues (colour coded red) where PI-resistance point mutations occurs. (C) Zoomed-in illustration showing in detail residues (colour coded blue) where major PI-resistance mutations occur. 
In contrast to the major PI resistance mutation discussed above; minor PI resistance mutations generally emerge later than major mutations and they do not have substantial effect on drug resistance phenotype by themselves. Instead, they improve replication of viruses containing major mutations (V. A. Johnson et al., 2010). For instance, minor mutations at amino acid residues L10, K20, M36, L63 and A71 up-regulates protease processivity to compensate for the decreased fitness associated with the major PI resistance mutations (Hoffman et al., 2003; Mammano et al., 1998; Martinez-Picado et al., 1999; Nijhuis et al., 1999; van Maarseveen et al., 2006). Residues L10, M36 and L63 are highly polymorphic. Baseline mutations at residues L10 and M36 are associated with an increased risk of virologic failure in patients receiving first generation PI such as nelfinavir (Perno et al., 2001; Perno et al., 2004). L10V and A71V/T minor mutations respectively occur in 5\% and 10\% of PI-naïve patients, and in much higher proportion of PI-experienced patients (Rhee et al., 2003). In comparison, L10F/R and A711/L minor mutations do not occur in the absence of PI therapy (Rhee et al., 2003). Additional PI-selected mutations include the highly polymorphic mutations I13V, D60E, I62V, V77I and I93L as well as several uncommon mutations including V11I, E34Q, E35G, K43T, K45I, K55R, Q58E, T74P/A/S, V75I, N83D, P79A/S, I85V, L89V, T91S, Q92K and C95F (Ceccherini-Silberstein et al., 2004; Parkin et al., 2003; Rhee et al., 2005; Svicher et al., 2005; Vermeiren et al., 2007; T. D. Wu et al., 2003).

The mechanism of some PI resistance mutations seems subtype-specific. For example, the accessory PI resistance mutations I13V, K20I, M36I and I93L represent the consensus variant in one or more non-subtype B isolates (Rhee et al., 2006a). Furthermore, although both D30N and L90M mutations occur in non-subtype B viruses during nelfinavir therapy, D30N point mutation occurs more commonly in subtype B viruses; while L90M occurs more commonly in subtypes C, F, G and circulating recombinant form-AE (CRF-AE) viruses (Abecasis et al., 2005; Calazans et al., 2005; Cane et al., 2001; Grossman et al., 2004; Sugiura et al., 2002). The increased predilection for a certain subtype to develop L90M may relate to the presence of variants other than L, which is subtype B consensus, at position 89 (Abecasis et al., 2005; Calazans et al., 2005; Gonzalez et al., 2004). Similarly, T74S, which is a polymorphism that occurs in $8 \%$ of subtype $\mathrm{C}$ sequences, but rarely in other subtypes, is associated with reduced susceptibility to nelfinavir (Deforche et al., 2007; Deforche et al., 2006; Rhee et al., 2006b). Notwithstanding, with notable aforementioned exceptions, the genetic mechanisms of PI resistance are highly similar among different subtypes (Kantor et al., 2005).

\subsection{Point mutations associated with resistance to integrase inhibitors}

The HIV-1 integrase catalyses the ligation of the viral $3^{\prime}-\mathrm{OH}$ end to the 5'-DNA of host chromosomal DNA through a process called the strand transfer (A. A. Johnson et al., 2006; Pommier et al., 2005). The current generation of clinically relevant INI drugs such as the recently USA Food and Drug Administration (FDA) approved raltegravir (FDA, 2007) and elvitegravir, currently undergoing phase III clinical trials (Gilead Sciences, 2008), preferentially inhibit strand transfer by binding to the target DNA site of the enzyme. Most INI resistance mutations are in the vicinity of the putative INI binding pocket (Figure 5). Some of the INI resistance mutations decrease susceptibility by themselves, whereas others compensate for the decrease fitness associated with other INI resistance mutations (Lataillade et al., 2007). There is a high level of cross-resistance between raltegravir and elvitegravir, as well as between these INI and the first generation of strand-transfer 
inhibitors, suggesting that the development of non cross-resistant INI will be challenging (Hombrouck et al., 2008; Shimura et al., 2008).

Common INI resistance point mutations are N155H and Q148H/R/K (Table 5), each of which can reduce raltegravir susceptibility by up to 25-fold (Cooper et al., 2008). Higher levels of raltegravir resistance occur with accumulation of additional mutations. E92Q mutation and the two polymorphic mutations L74M and G163R generally occur with N155H, while G140A/S generally occurs with Q148H/R/K (Cooper et al., 2008). Additional mutations (listed in Table 4) have been reported as being selected either in vitro or in vivo by raltegravir and include the non-polymorphic L74R, E138A/K, Y143R/C/H, N155S, H183P, Y226D/F/H, S230R, and D232N and the polymorphic mutations T97A and V151I (Delelis et al., 2011; Malet et al., 2008; Mouscadet et al., 2009). For both raltegravir and elvitegravir, virologic failure has generally been accompanied by 100-fold or greater decreases in susceptibility and the development of two or more INI resistance mutations. Mutations at amino acid residues E92, F121, G140, Q148 and N155 are associated with more than 10-fold decrease in susceptibility to both INI, whereas mutations at amino acid residues T66 and S147 are associated with marked decreases in susceptibility only to elvitegravir (Figure 5 and Table 5).

\begin{tabular}{|c|c|c|c|c|c|c|c|c|c|c|c|c|c|c|c|c|c|}
\hline PI & \multicolumn{17}{|c|}{ Major mutations } \\
\hline * & L23 & $\begin{array}{c}\mathrm{L} 2 \\
4\end{array}$ & D30 & $\begin{array}{c}\text { V3 } \\
2\end{array}$ & L33 & M46 & I47 & G48 & I50 & $\begin{array}{c}\mathrm{F} 5 \\
3 \\
\end{array}$ & $\mathrm{I} 54$ & $\begin{array}{c}\text { G7 } \\
3\end{array}$ & $\begin{array}{c}\text { L7 } \\
6\end{array}$ & V82 & 184 & N88 & L90 \\
\hline ATVr & - & I & - & - & $\mathrm{F}$ & IL & V & VM & L & $\underline{\mathrm{L}}$ & VTALM & ST & - & ATFS & VAC & $\mathrm{D} \underline{\mathbf{S}}$ & $\mathbf{M}$ \\
\hline $\mathrm{DRVr}$ & - & - & - & I & $\mathrm{F}$ & - & VA & - & $\mathrm{V}$ & - & LM & ST & V & - & VAC & - & $\mathrm{M}$ \\
\hline $\mathrm{FPVr}$ & - & - & - & $\underline{\mathbf{I}}$ & $\mathrm{F}$ & IL & VA & - & $\mathbf{V}$ & - & VTALM & ST & $\mathbf{V}$ & ATFS & VAC & - & $\mathbf{M}$ \\
\hline INDVr & - & I & - & V & - & IL & V & - & - & L & VTALM & ST & $\mathrm{V}$ & $\underline{\text { AFTS }}$ & VAC & $S$ & M \\
\hline LPVr & - & I & - & I & $\mathrm{F}$ & IL & V $\underline{A}$ & VM & $\mathbf{V}$ & - & VTALM & - & $\mathbf{V}$ & AFTS & VAC & - & M \\
\hline NFV & $\underline{\mathbf{I}}$ & I & $\underline{\mathbf{N}}$ & - & $\mathrm{F}$ & $\underline{\text { IL }}$ & V & $\underline{\mathrm{VM}}$ & - & L & VTALM & ST & - & AFTS & VAC & $\underline{\text { DS }}$ & $\underline{\mathbf{M}}$ \\
\hline SQVr & - & I & - & - & - & - & - & $\underline{\text { VM }}$ & - & $\mathrm{L}$ & VTALM & ST & - & AT & VAC & $\mathrm{S}$ & $\underline{\mathbf{M}}$ \\
\hline $\mathrm{TPVr}$ & - & - & - & I & $\mathrm{F}$ & IL & V & - & - & - & VAM & - & - & A프느 & VAC & - & M \\
\hline
\end{tabular}

*Denotes position of consensus amino acids that confer resistance to PI when mutated. Dashes (-) indicate that the respective PI are not affected by the mutation(s). All amino acids are denoted by the single letter annotation. Mutations in bold are associated with high levels of phenotypic resistance or reduced virologic response. Mutations in bold underline are relative contraindications to the use of specific PI. ATVr (atazanavir/r); DRVr (darunavir/r); FPVr (fosamprevanir); IDVr (indinavir/r); NFV (nelfinavir); SQVr (saquinavir/r); TPVr (tipranavir/r). Modified from (Shafer \& Schapiro, 2008).

Table 4. Mutations in the protease gene associated with major resistance to PI

INI

\begin{tabular}{||c|c|c|c|c|c|c|c|c|c|c|c|c|}
\hline$*$ & T66 & E92 & F121 & E138 & G140 & Y143 & S147 & Q148 & S153 & N155 & E157 & R263 \\
\hline Raltegravir & - & Q & Y & AK & AS & CHR & G & HRK & - & HS & Q & - \\
\hline Elvitegravir & I & Q & Y & AK & AS & - & G & HRK & Y & HS & Q & K \\
\hline
\end{tabular}

*Denotes position of consensus amino acids that confer resistance to INI when mutated. Dashes (-) indicate that the respective INI are not affected by the mutation(s). All amino acids are denoted by the single letter annotation. Mutations in bold are associated with more than 5-10 fold phenotypic resistance or reduced virologic response. Modified from (Shafer \& Schapiro, 2008).

Table 5. Mutations in the integrase gene associated with resistance to INI 

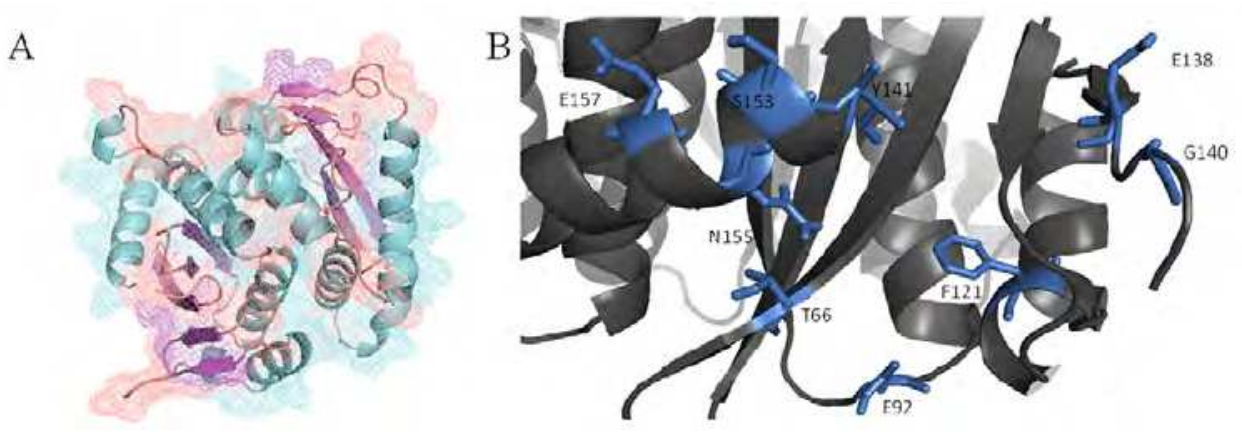

Fig. 5. Crystal structure of HIV-1 integrase showing the residues where major INI-resistance mutations occur. (A) Mesh illustration of bound HIV-1 integrase. (B) Illustration of amino acid residues where INI-resistance point mutations occurs.

\subsection{Point mutations associated with resistance to fusion inhibitors}

The HIV-1 gp41 mediates the fusion between the virus and host cell membrane. Fusion inhibitors act by a dominant negative mechanism of action, preventing formation of the sixhelix bundle that is the driving force for the fusion process. Enfurvirtide, also known as T20 (Kilby et al., 1998; Wild et al., 1994), is the only FDA approved fusion inhibitor to date. Enfurvirtide has antiviral activity similar to most other classes of antiretroviral drugs discussed above; however resistance develop rapidly in patients receiving the drug for salvage therapy who do not receive a sufficient number of RTI, PI and INI drugs such as efavirenz, lopinanir/ $\mathrm{r}$ and raltegravir, respectively. The emergence of enfurvirtide resistant strains followed by virologic rebound has been observed in some patients within two to four weeks (Cabrera et al., 2006; Lu et al., 2006).

Mutations in gp41 codons 36 to 45 (Figure 6), the region to which enfurvirtide binds, are primarily responsible for resistance to the drug (Marcelin et al., 2004c; Melby et al., 2006; Menzo et al., 2004; Mink et al., 2005; Sista et al., 2004; Su et al., 2006). The most common and potent T20-resistance mutations in this region are G36D/E, V38E/A, Q40H and N43D/K/S (Table 6). A single point mutation is generally associated with about 10 -fold decreased susceptibility; whereas double point mutations can decrease susceptibility by more than 100-fold (Charpentier et al., 2011; Su et al., 2006; Xu et al., 2005). The replication fitness of recombinant viruses carrying the enfurvirtide-resistant mutations is relatively poor (Lu et al., 2004) and the mutant viruses rapidly revert to wild type phenotype in patients who discontinue the drug (Deeks et al., 2007). Some enfurvirtide-resistant mutations, particularly V38A/E mutations, are associated with significant CD4 count increases (Aquaro et al., 2006), presumably because mutations at residue V38 decrease HIV-1 replication or render the virus more susceptibility to a subset of neutralizing antibodies that target fusion intermediates (Reeves et al., 2005). 


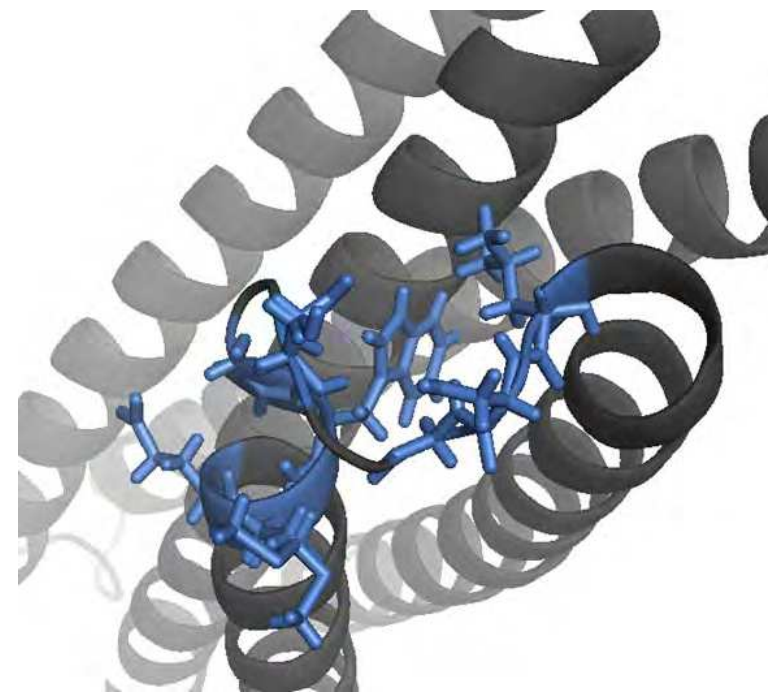

Fig. 6. Ribbon representation of HIV-1 heptad repeat fusogenic domain showing point mutations (colour coded blue) that cause resistance to fusion inhibitors.

\begin{tabular}{|c|c|c|c|c|c|c|c|c|c|}
\hline $\begin{array}{c}\text { Fusion } \\
\text { inhibitor }\end{array}$ & \multicolumn{10}{|c|}{ Mutations } \\
\hline$*$ & G36 & I37 & V38 & Q39 & Q40 & N42 & N43 & L44 & L45 \\
\hline Enfuvirtide & DEVS & V & EAMG & R & H & T & DKS & M & M \\
\hline
\end{tabular}

*Denotes position of consensus amino acids that confer resistance to enfuvirtide when mutated. All amino acids are denoted by the single letter annotation. Mutations in bold are associated with more 10fold phenotypic resistance or reduced virologic response in most clinical isolates. Modified from (Shafer \& Schapiro, 2008).

Table 6. Mutations in the gp41 env gene associated with resistance to fusion inhibitors

\subsection{Point mutations associated with resistance to attachment inhibitors}

Despite the important role gp120 plays in attachment of HIV-1 to the CD4 receptor and CCR5/CXCR4; maraviroc, which is a CCR5 antagonist, is the only FDA approved attachment inhibitor in clinical use to date. While gp120 binds to the N-terminus and the second extracellular loop region of CCR5 (Hartley et al., 2005), site-directed mutagenesis study suggests that small molecule attachment inhibitors such as maraviroc bind to a CCR5 pocket formed by the transmembrane helices (Dragic et al., 2000). Thus, although gp120 and maraviroc do not bind to the same site of the CCR5 coreceptor, maraviroc allosterically inhibit gp120 binding to the CCR5 coreceptor. Point mutations in gp120 that allow the virus to bind to the maraviroc-bound form of CCR5 in the drug insensitive manner have been described (Westby et al., 2007). Most of these mutations are found in the V3 loop of gp120 (Figure 7A), which determines HIV-1 tropism (discussed in the next section). One study showed that reverse mutations at positions 316 and 323 in the V3 loop of maraviroc-resistant HIV-1 variants to their original sequence restored wild-type susceptibility to maraviroc, 
while reversion of either mutation resulted in a partially sensitive virus with reduced maximal inhibition (Westby et al., 2007). In another recent study maraviroc-resistant variants were isolated from the V3 loop library virus (HIV-1(V3lib)) containing the T199K and T275M plus 5 mutations in the V3 loop, namely I304V; F312W; T314A; E317D; I318V (Yuan et al., 2011). Furthermore, the same study showed that the profile of HIV-1(JR-FL) pseudotype containing I304V/F312W/T314A/E317D/I318V (Figure 7A) in the V3 loop alone revealed a typical non-competitive resistance to maraviroc (Yuan et al., 2011). Generally, amino acids mutations in the V3 loop may include known polymorphism as well as novel substitutions, insertions, and deletions. Further complicating the genetic basis of maraviroc or CCR5 inhibitor resistance is the observation that the same inhibitor may select for different mutations in different HIV-1 isolates (Westby et al., 2007). The mutations observed in maraviroc-resistant strains isolated from patients are variable and differed for each HIV-1 isolate (Seclen et al., 2011; Tilton et al., 2011).
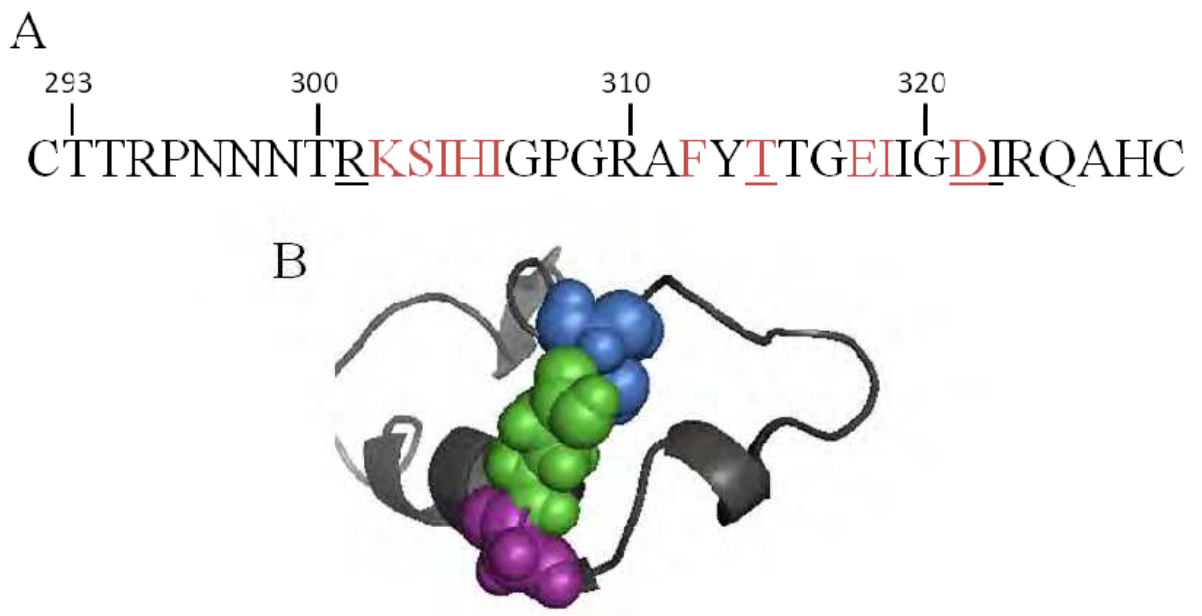

Fig. 7. Illustration of amino acid residues in the V3 loop important for HIV-1 tropism and resistance to maraviroc. (A) The sequence of the V3 variable loop indicating the sites of unique X4 substitution sites when compared to R5 clones (underlined). The red residues indicate the positions where maraviroc resistance mutations occur. Together with T199K and $\mathrm{T} 275 \mathrm{M}$, these mutations confer complete resistance to maraviroc. (B) Ribbon diagram of gp120 V3 variable loop highlighting amino acid residues essential for co-receptor usage. X4 tropism is determined by positively charged residues at position 11, 24 and 25 (colour coded blue, green and magenta respectively). R5 tropism is determined by a negative or neutral residue at any of the three positions.

\section{Point mutations associated with HIV-1 tropism, transmission dynamics and AIDS pathogenesis}

The identification of CCR5 and CXCR4 chemokine receptors as having critical roles in the cellular entry of HIV-1 allowed development of a more precise system for defining the viral tropism. Prototype T-cell tropic strains use CXCR4, macrophage-tropic strains use CCR5, 
and dual-tropic strains use both CXCR4 and CCR5 chemokine receptors, culminating in the currently used nomenclature X4, R5 and R5X4 strains, respectively (Berger et al., 1998). The phenotype of HIV-1 that is transmitted in vivo is R5 even when the contaminating virus is a mixture of R5, R5X4 and X4. The reason for this selection of viral phenotype during transmission is not well understood. The viraemia present during primary infection consists of oligoclonal R5 virus, and this virus type generally persists during the asymptomatic phase of the infection until the onset of AIDS. Viral transmission and disease progression, collectively called AIDS pathogenesis, corresponds to evolution of coreceptor phenotype. In about half of all HIV-1 infections there is viral evolution towards dual (R5X4) tropism and CXCR4 usage that is prognostic for accelerated progression to AIDS (Collman et al., 1992; Doranz et al., 1996). Thus when the phenotype switch occurs, there is an initial evolution from CCR5 using viruses to those that can use both CCR5 and CXCR4 (Connor et al., 1997). While evolution towards usage of the CXCR4 coreceptor and emergence of X4 viruses coincides with a decline in $\mathrm{CD} 4^{+} \mathrm{T}$ cells and the onset of AIDS, the dominant theory is that $\mathrm{X} 4$ viruses are opportunistic infections that can only appear once the $\mathrm{CD}^{+} \mathrm{T}$ cells have dropped below a certain threshold level. Notwithstanding, in another $50 \%$ of individuals infected with HIV-1 there is no viral evolution towards CXCR4 usage or emergence of X4 viruses; R5 viruses persists from primary infection until one succumbs to AIDS. This suggests that R5 viruses are necessary and sufficient to cause AIDS.

The main determinants for coreceptor tropism resides in the V3 loop (Figure 7), although mutations outside of the V3 loop may also influence tropism, either in combination or independently of the V3 mutations (Hartley et al., 2005; W. Huang et al., 2008; Pastore et al., 2007; Pastore et al., 2006). Very few mutations in the V3 loop are sufficient for switching coreceptor use from CCR5 to CXCR4 in most HIV-1 isolates, but in some isolates additional mutations in V1/V2 (Pastore et al., 2006) and gp41 (W. Huang et al., 2008) are observed during coreceptor switching. The presence of positively charged amino acids at positions 11, 24 and 25 in the V3 loop, combined with other V3 sequence characteristics (Figure 7), have specificity of about $90 \%$ and sensitivity of $70-80 \%$ for predicting X4 tropism (Hartley et al., 2005; Jensen \& van 't Wout, 2003; Sing et al., 2007). However, the number and type of mutations by which an R5 virus switches to X4 is complex and depends on the sequence of the baseline R5 virus (Low et al., 2007; Moncunill et al., 2008; Pastore et al., 2007; Pastore et al., 2006). The frequency and genetic basis for tropism switch is different for different HIV-1 subtypes (Hartley et al., 2005; W. Huang et al., 2007). While differential use of CXCR4 or CCR5 by HIV-1 strains has been observed, the striking differences seen appear to be in how R5 and R5X4 viruses utilize the CCR5 coreceptor. Generally, R5-tropic viruses are particularly well adapted for CCR5 use (Choe et al., 1996; Deng et al., 1996; Dragic et al., 1996), and can tolerate deletion or substitution of the CCR5 amino-terminal domain (Howard et al., 1999; Z. Wang et al., 1999). R5X4 viruses, however, are much more sensitive to mutations in CCR5, particularly in the amino terminal domain (Doranz et al., 1997). Thus, there is a cost associated with the benefit to use dual chemokine receptors as exhibited by R5X4 tropic strains that have more stringent requirements for CCR5 usage (Rana et al., 1997).

Host genetic factors can also influence HIV-1 tropism and transmission. Cohorts of HIV-1 infected individuals have been established based on specific clinical, virological and immunological criteria. One type of cohort contains individuals selected after frequent 
exposure to HIV-1 without seroconversion. A mutation in the CCR5 gene has been frequently found in this type of cohort (Zimmerman et al., 1997). This mutation is a deletion of 32 base pairs $(\Delta 32)$, resulting in a defective CCR5 receptor. CD4 $4^{+} \mathrm{T}$ cells and macrophages carrying the $\Delta 32$ mutation are resistant to infection with $\mathrm{R} 5$ viruses. Homozygous individuals carrying the mutation on both alleles ( $1 \%$ of Caucasians) are almost completely refractory to infection with R5 HIV-1 strains (Samson et al., 1996; Zimmerman et al., 1997). Very rare examples of infection of these individuals have been reported (O'Brien et al., 1997; Theodorou et al., 1997). In these cases the transmitted R5 viruses appear to use CXCR4. Individuals heterozygous for the $\Delta 32$ mutation are not protected from HIV-1 infection, but have slower rate of progression to AIDS. This is because the mutated form of the protein acts as a dominant negative mutant and prevents most of the wild-type CCR5 protein from reaching the cell surface. However, HIV-1 can evolve adaptive mutations on the V3 loop of gp120 that allows it to use defective or mutant CCR5 co-receptor. For instance, it has been shown that a N300Y adaptive point mutation on the V3 loop of gp120 enhances binding of HIV-1 to the mutant CCR5 coreceptor (Platt et al., 2001). A follow-up study from the same group has shown that in addition to the adaptive mutation on the V3 loop of gp120, an S193N point mutation on the V2 stem and loss of N-linked oligosaccharide from position N403 of gp120 help HIV-1 to efficiently use defective CCR5 co-receptor that has a badly damaged amino terminus (Platt et al., 2005). Taken together, these studies have important implications for understanding HIV-1 transmission dynamics and AIDS pathogenesis.

AIDS pathogenesis is multifactorial; it is a mixture of host and pathogen genetics combined with factors such as the immune response and viral adaptation. Viral adaptation include reverting and compensatory mutations such as the recently described T242N point mutation on the gag gene associated with progression to AIDS in South African patients (K. H. Huang et al., 2011). However in general, progression from acute infection is often accompanied by depletion of the $\mathrm{CD}^{+}$lymphocytes and this depletion is a major component of the eventual failure of the immune system and hence AIDS pathogenesis. Apoptosis is one mechanism that contributes to depletion of HIV-1 infected and uninfected cells, deterioration of the immune system and progression to AIDS, respectively (Cotton et al., 1997; Gougeon \& Montagnier, 1993; Herbein et al., 1998; Joshi et al., 2011; C. J. Li et al., 1995; Zhu et al., 2011). HIV-induced apoptosis is triggered by a number of HIV-1 proteins, notably the envelope protein (Herbein et al., 1998; Ishikawa et al., 1998; Joshi et al., 2011; Micoli et al., 2006; Micoli et al., 2000). Four point mutations (A835W, A838W, A838I, and I842R) in the cytoplasm domain of the gp41 subunit of the envelope protein reduces HIV-induced apoptosis of target cells (Micoli et al., 2006). A recent study has shown that induction of bystander apoptosis in CCR5 expressing cells requires the fusogenic activity of gp41; and that V2E and V38A/E point mutation in the second amino acid and the heptad repeat 1 region of gp41 respectively, abrogated fusion activity and hence apoptosis induced by an R5 virus (Joshi et al., 2011). In an earlier study, the same group showed that a V513E point mutation in the fusion domain of gp41 resulted in a fusion-defective envelope protein that failed to induce apoptosis and that a G547D mutation in the gp41 N-terminal helix also reduced cell fusion capacity and apoptosis induced by an X4 virus (Garg et al., 2007). 


\section{Point mutations associated with evasion of antibody mediated immune response}

Point mutations on HIV-1 envelope protein do not only influence HIV-1 tropism and disease progression, but they also help the virus to evade the antibody mediated immune response. The HIV-1 surface gp120 and the trans-membrane gp41 can elicit both virus-neutralizing and non-neutralizing antibodies during natural infection. Antibodies that lack neutralizing activity are often directed against the gp120 regions that are occluded on the assembled trimer, and which are exposed only upon shedding (Moore \& Sodroski, 1996). Neutralizing antibodies, by contrast must access the functional envelope glycoprotein complex and typically recognize conserved or variable epitopes near the receptor binding sites (Posner et al., 1991; Sattentau \& Moore, 1995; Trkola et al., 1996a; L. Wu et al., 1996). Neutralising antibodies are also elicited by the membrane proximal external region (MPER) of gp41 (Frey et al., 2008; J. Wang et al., 2011; Zwick et al., 2001). The production and characterization of monoclonal antibodies of human and rodent origin have allowed a precise determination of the neutralization epitopes present on the HIV-1 gp120 (Moore \& Ho, 1995; Poignard et al., 1996).

Using epitope maps in conjunction with the X-ray crystal structure of gp120 complexed with CD4 and a neutralizing monoclonal antibody (Kwong et al., 1998b), spatial organization of conserved neutralization epitopes on gp120 was determined (Wyatt et al., 1998). More broadly neutralizing antibodies recognize discontinuous, conserved epitopes in three regions of the gp120 (Figure 8). In HIV-1 infected individuals, the most abundant of these are directed against the CD4 binding site (CD4bs), and block gp120-CD4 interaction (Euler et al., 2011; Ho et al., 1991; Y. Li et al., 2011; Posner et al., 1991; Walker et al., 2009; X. Wu et al., 2010; Zhou et al., 2011). Less common are antibodies against epitopes induced or exposed upon CD4 binding (CD4i) (Thali et al., 1993). Both CD4i and V3 antibodies disrupt the binding of gp120-CD4 complexes to chemokine receptors (Trkola et al., 1996a; L. Wu et al., 1996). Notwithstanding, none of the CD4i antibodies discovered to date such as $17 \mathrm{~b}, 48 \mathrm{~d}$ or X5 are broadly neutralizing. A third gp120 neutralization epitope is defined by a unique monoclonal antibody, 2 G12 (Trkola et al., 1996b), which does not efficiently block receptor binding (Trkola et al., 1996a). Table 6 lists broadly neutralising monoclonal antibodies elicited by the HIV-1 gp120 and gp41 envelope proteins. Although high-titer antibodies are sustained in infected individuals throughout the course of infection, these antibodies have very poor neutralizing activity against autologous as well as representative primary HIV-1 isolates (Montefiori et al., 1996; Moog et al., 1997). This observation suggests that neutralizing antibodies that arise in response to HIV-1 infection may not be critical in limiting viral replication.

The escape of HIV-1 from effects of neutralizing antibodies includes mutations in gp120 and/or gp41. One of the seminal studies showed that A582T point mutation in the HIV-1 envelope gene made a laboratory adapted HIV-1 strain called HXB2 to be resistant to HIV-1 neutralizing human serum (Reitz et al., 1988). Another study published ten years later, showed that HIV-1 MN molecular clones which had 294N/K mutation before the V3 loop, 307N/I mutation proximal to the V3 loop, 327I/K mutation within V3 and 336N/I mutation after the V3 loop were resistant to human serum containing neutralizing antibodies directed at the immunodominant V3 loop of gp120 (Park et al., 1998). Point mutations in a highly conserved structural motif within the intracytoplasmic tail of gp41 rendered HIV-1 molecular clones resistant to broadly neutralizing polyclonal human serum antibodies (Kalia et al., 2005). 


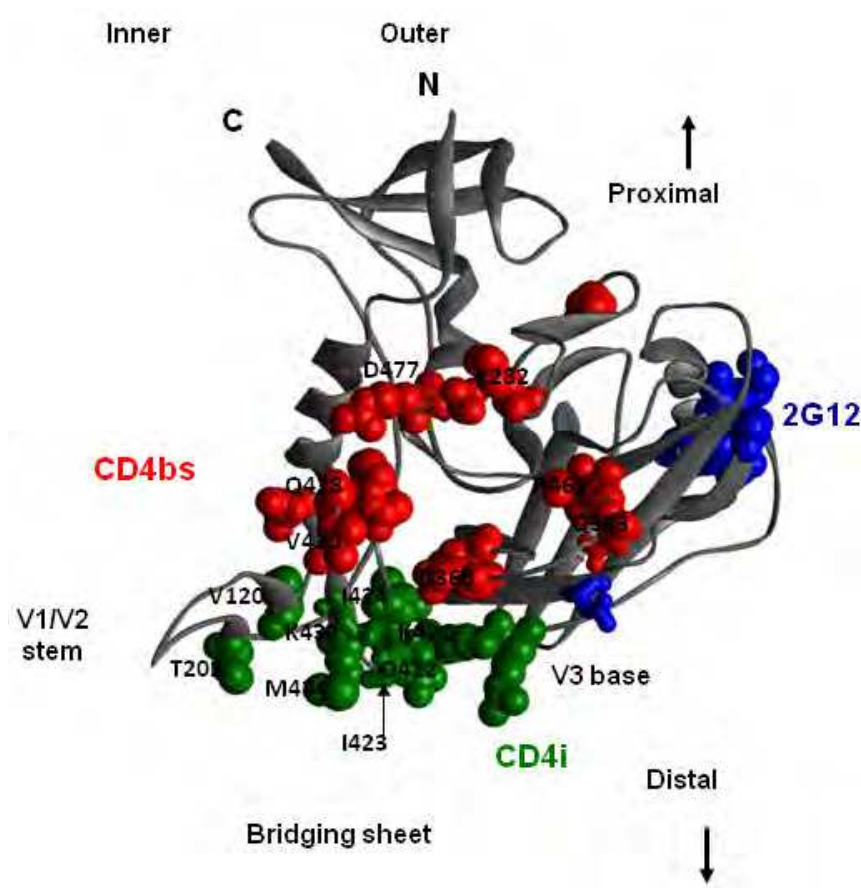

Fig. 8. Ribbon diagram illustrating epitopes of the gp120 core, highlighting some amino acid residues that interact with broadly neutralizing antibodies. The CD4bs (red) and the CD4i co-receptor-binding surface (green) as well as residues implicated in 2G12 binding (blue) are depicted.

In a clinically relevant study, paediatric HIV-1 subtype C clinical isolates with K665S/R/N point mutation were found to be resistant to a $2 \mathrm{~F} 5$ broadly neutralizing monoclonal antibody (Gray et al., 2006). This study confirmed earlier findings that the amino acid residue K665 is crucial for neutralization by 2F5 (Binley et al., 2004). In the same study, the Lynn Morris' group found out that all the paediatric HIV-1 subtype C clinical isolates analysed had a conserved 4E10 epitope (W672, F673, W680) consistent with their phenotypic sensitivity to the $4 \mathrm{E} 10$ monoclonal antibody (Gray et al., 2006). $4 \mathrm{E} 10$ recognizes an epitope containing the sequence NWF(D/N)IT (Zwick et al., 2001). Mutagenesis studies have shown that the amino acid residues W672, F673 and W680 are indispensable for recognition by $4 \mathrm{E} 10$ (Zwick et al., 2005). Indeed, a recently published study describing four subjects infected with viruses carrying rare MPER polymorphisms associated with resistance to 4 E10 neutralization has shown that three subjects had W680 polymorphism, including a W680G point mutation (Nakamura et al., 2011). The study demonstrated that W680G point mutation was necessary to confer 4 E10 resistant phenotype (Nakamura et al., 2011). In another subject a W680R point mutation caused variable resistant to 4E10 (Nakamura et al., 2011). A fourth subject possessed a F673L point mutation also associated with 4E10 resistance (Nakamura et al., 2011). Earlier, an independent study conducted in South Africa also showed that an HIV-1 subtype C virus isolated from a 7-year-old 
perinatally infected child with F673L point mutation was resistant to $4 \mathrm{E} 10$ (Gray et al., 2008). These case studies are examples of the challenges presented by point mutations in controlling HIV-1 infection by antibodies. Notwithstanding, recent discovery of additional and more potent broadly neutralizing antibodies such as VRC01 (X. Wu et al., 2010), PG9 and PG16 (Walker et al., 2009) is encouraging and boosts the impetus for HIV-1 vaccine design that may elicit broadly neutralizing antibodies (Burton \& Weiss, 2010).

\begin{tabular}{|c|c|c|c|c|}
\hline Epitopes & $\begin{array}{c}\text { Example } \\
\text { of } \mathrm{mAb}\end{array}$ & $\begin{array}{l}\text { Mechanism of } \\
\text { neutralization }\end{array}$ & Properties & Selected references \\
\hline $\begin{array}{c}\text { CD4 } \\
\text { binding } \\
\text { site(CD4bs) }\end{array}$ & $\begin{array}{l}\text { IgGb12, } \\
\text { VRC01, } \\
\text { HJ16, } \\
\text { PG9 and } \\
\text { PG16 }\end{array}$ & $\begin{array}{l}\text { Interfere with } \\
\text { gp120-CD4 } \\
\text { binding }\end{array}$ & $\begin{array}{l}\text { CD4bs antibodies compete } \\
\text { with CD4 and with } \\
\text { antibodies against CD4i } \\
\text { epitope. } \\
\text { PG9 and PG16 bind to } \\
\text { trimer specific } \\
\text { glycosylated epitope on } \\
\text { the V1/V2 and V3 region. }\end{array}$ & $\begin{array}{l}\text { (Corti et al., 2010; Euler } \\
\text { et al., 2011; Ho et al., } \\
\text { 1991; Y. Li et al., 2011; } \\
\text { Pancera et al., 2010; } \\
\text { Posner et al., 1991; } \\
\text { Walker et al., 2009; X. } \\
\text { Wu et al., 2010; Zhou et } \\
\text { al., 2011) }\end{array}$ \\
\hline Glycans & 2G12 & $\begin{array}{l}\text { Interfere with } \\
\text { binding of gp120 } \\
\text { to CCR5 } \\
\text { chemokine } \\
\text { receptor and } \\
\text { DC-SIGN. Also } \\
\text { prevent loss of } \\
\text { CD4+ T cells. }\end{array}$ & $\begin{array}{c}\text { Antibody binding is } \\
\text { dependent upon proper } \\
\text { N-linked glycosylation. } \\
\text { Recognize a mannose rich } \\
\text { epitope on the "silent" face } \\
\text { of gp120 }\end{array}$ & $\begin{array}{l}\text { (Binley et al., 2006; } \\
\text { Calarese et al., 2003; } \\
\text { Luo et al., 2011; Scanlan } \\
\text { et al., 2003; Trkola et al., } \\
\text { 1996b) }\end{array}$ \\
\hline $\begin{array}{l}\text { MPER of } \\
\text { gp41 }\end{array}$ & $\begin{array}{c}4 \mathrm{E} 10 \\
2 \mathrm{~F} 5\end{array}$ & $\begin{array}{l}\text { Interfere with } \\
\text { HIV-1 fusion } \\
\text { and induces } \\
\text { shedding of } \\
\text { gp120. }\end{array}$ & $\begin{array}{l}\text { Both antibodies bind few } \\
\text { crucial residues in the } \\
\text { MPER of gp41. HIV-1 2F5 } \\
\text { binds both native and } \\
\text { fusion-intermediate } \\
\text { conformations while } 4 \mathrm{E} 10 \\
\text { recognize a predominantly } \\
\text { linear and relatively } \\
\text { conserved epitope. }\end{array}$ & $\begin{array}{l}\text { (Muster et al., 1994; } \\
\text { Muster et al., 1993; } \\
\text { Ruprecht et al., 2011; } \\
\text { Zwick et al., 2005; } \\
\text { Zwick et al., 2001) }\end{array}$ \\
\hline
\end{tabular}

Table 8. Broadly neutralizing antibodies that bind gp120 and gp41 HIV-1 envelope proteins

\section{Point mutations and anti-gp120 aptamers}

Aptamers are synthetic oligonucleotide ligands that can be isolated in vitro against diverse targets including HIV-1 gp120 (Khati et al., 2003). Aptamers assume a defined threedimensional structure and generally bind functional sites on their respective targets. They possess the molecular recognition properties of monoclonal antibodies in terms of their high affinity and specificity (Khati, 2010). Unlike antibodies, aptamers can fold properly and retain activity in the intracellular environment. However, the majority of aptamers with potential therapeutic utility selected to date target extracellular proteins (Chen et al., 2003; Eyetech Study Group, 2002, 2003; Green et al., 1995; Kim et al., 2003; Liu et al., 2009; Lupold et 


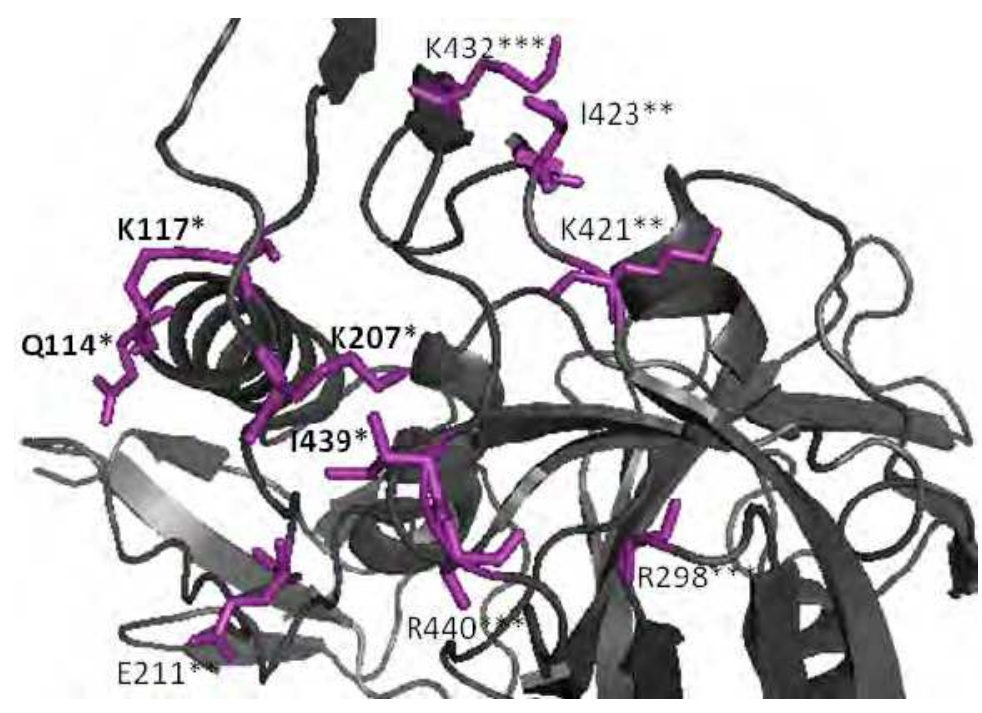

Fig. 9. A ribbon diagram of gp120 highlighting amino acid residues that interact with B40 aptamer. Residues in bold and single asterix are highly conserved among all HIV-1 isolates and significantly reduced binding of the aptamer by more than 10-fold when experimentally mutated to alanine, respectively (Joubert et al., 2010). Those residues with double or tripple asterix are moderately and significantly varaiable, respectively, in all HIV isolates and while they make contact with the aptamer they did not significantly affect binding of the aptamer when experimentally mutated to alanine, respectively.

al., 2002; Mi et al., 2009; Nobile et al., 1998; Ruckman et al., 1998; Rusconi et al., 2004; Rusconi et al., 2002; Vinores, 2003; White et al., 2003).

Extracellular therapeutic targets such as HIV-1 gp120 have the advantage of ready access to aptamer intervention without the need for enabling access to cells. The aptamers against HIV-1 gp120 bound the protein with high affinity, high specificity and neutralized a broad range of R5 HIV-1 clinical isolates (Khati et al., 2003). In a recent review, these RNA aptamers were reported to have the most potent in vitro antiviral efficacy of all HIV-1 entry inhibitors described to date (Held et al., 2006), including antibodies. These aptamers prevented entry and suppressed viral replication in cultured human peripheral blood mononuclear cells (PBMC) by up to 10,000-fold (Khati et al., 2003). While the emergence of HIV-1 escape mutants and drug resistance variants appears to be inevitable, our goup and collaborators have recently shown that one extensively studied aptamer called B40 penetrate the highly variable exterior surfaces of gp120 and bind the conserved core at the heart of the CCR5-binding site (Cohen et al., 2008; Dey et al., 2005; Joubert et al., 2010), which the virus may be unable to mutate without compromising its fitness. Four amino acids (Q114, K117, K207, and I439) of gp120 (Figure 9) that weakened binding of gp120 to B40 aptamer by at least 10-fold when experimentally mutated to alanine (Joubert et al., 2010) are naturally conserved among all HIV-1 isolates (Kwong et al., 1998a). This suggests that B40 makes direct contact with at least four conserved core residues on gp120 within the CCR5-binding site, which the virus cannot afford to mutate without losing selective advantage. These data 
bode well for the future development of aptamers such as B40 as an entry inhibitor drug, which will hopefully help circumvent HIV-1 point mutations and delay or diminish drug resistance. In order to maximally suppress or eradicate the virus; the aptamer or any other anti-HIV molecule in development should be used in combination with current antiretroviral drugs and the envisaged vaccines currently developed to elicit broadly neutralising antibodies.

\section{References}

Abecasis, A. B., Deforche, K., Snoeck, J., Bacheler, L. T., McKenna, P., Carvalho, A. P., Gomes, P., Camacho, R. J., \& Vandamme, A. M. (2005). Protease mutation M89I/V is linked to therapy failure in patients infected with the HIV-1 non-B subtypes C, F or G. Aids, 19(16), 1799-1806.

Antinori, A., Trotta, M. P., Lorenzini, P., Torti, C., Gianotti, N., Maggiolo, F., CeccheriniSilberstein, F., Nasto, P., Castagna, A., De Luca, A., Mussini, C., Andreoni, M., \& Perno, C. F. (2007). Virological response to salvage therapy in HIV-infected persons carrying the reverse transcriptase K65R mutation. Antivir Ther, 12(8), 1175-1183.

Antinori, A., Zaccarelli, M., Cingolani, A., Forbici, F., Rizzo, M. G., Trotta, M. P., Di Giambenedetto, S., Narciso, P., Ammassari, A., Girardi, E., De Luca, A., \& Perno, C. F. (2002). Cross-resistance among nonnucleoside reverse transcriptase inhibitors limits recycling efavirenz after nevirapine failure. AIDS Res Hum Retroviruses, 18(12), 835-838.

Aquaro, S., D'Arrigo, R., Svicher, V., Perri, G. D., Caputo, S. L., Visco-Comandini, U., Santoro, M., Bertoli, A., Mazzotta, F., Bonora, S., Tozzi, V., Bellagamba, R., Zaccarelli, M., Narciso, P., Antinori, A., \& Perno, C. F. (2006). Specific mutations in HIV-1 gp41 are associated with immunological success in HIV-1-infected patients receiving enfuvirtide treatment. J Antimicrob Chemother, 58(4), 714-722.

Arion, D., Kaushik, N., McCormick, S., Borkow, G., \& Parniak, M. A. (1998). Phenotypic mechanism of HIV-1 resistance to 3'-azido-3'-deoxythymidine (AZT): increased polymerization processivity and enhanced sensitivity to pyrophosphate of the mutant viral reverse transcriptase. Biochemistry, 37(45), 15908-15917.

Arnold, E., Jacobo-Molina, A., Nanni, R. G., Williams, R. L., Lu, X., Ding, J., Clark, A. D., Jr., Zhang, A., Ferris, A. L., Clark, P., \& et al. (1992). Structure of HIV-1 reverse transcriptase/DNA complex at $7 \mathrm{~A}$ resolution showing active site locations. Nature, 357(6373), 85-89.

Bacheler, L., Jeffrey, S., Hanna, G., D'Aquila, R., Wallace, L., Logue, K., Cordova, B., Hertogs, K., Larder, B., Buckery, R., Baker, D., Gallagher, K., Scarnati, H., Tritch, R., \& Rizzo, C. (2001). Genotypic correlates of phenotypic resistance to efavirenz in virus isolates from patients failing nonnucleoside reverse transcriptase inhibitor therapy. J Virol, 75(11), 4999-5008.

Baxter, J. D., Schapiro, J. M., Boucher, C. A., Kohlbrenner, V. M., Hall, D. B., Scherer, J. R., \& Mayers, D. L. (2006). Genotypic changes in human immunodeficiency virus type 1 protease associated with reduced susceptibility and virologic response to the protease inhibitor tipranavir. J Virol, 80(21), 10794-10801.

Berger, E. A., Doms, R. W., Fenyo, E. M., Korber, B. T., Littman, D. R., Moore, J. P., Sattentau, Q. J., Schuitemaker, H., Sodroski, J., \& Weiss, R. A. (1998). A new classification for HIV-1 [letter]. Nature, 391(6664), 240.

Binley, J. M., Ngo-Abdalla, S., Moore, P., Bobardt, M., Chatterii, U., Gallay, P., Burton, D. R., Wilson, I. A., Elder, J. H., \& de Parseval, A. (2006). Inhibition of HIV Env binding to 
cellular receptors by monoclonal antibody $2 \mathrm{G} 12$ as probed by Fc-tagged gp120. Retrovirology, 3, 39.

Binley, J. M., Wrin, T., Korber, B., Zwick, M. B., Wang, M., Chappey, C., Stiegler, G., Kunert, R., Zolla-Pazner, S., Katinger, H., Petropoulos, C. J., \& Burton, D. R. (2004). Comprehensive cross-clade neutralization analysis of a panel of anti-human immunodeficiency virus type 1 monoclonal antibodies. J Virol, 78(23), 13232-13252.

Boyer, P. L., Sarafianos, S. G., Arnold, E., \& Hughes, S. H. (2001). Selective excision of AZTMP by drug-resistant human immunodeficiency virus reverse transcriptase. $J$ Virol, 75(10), 4832-4842.

Brenner, B. G., Oliveira, M., Doualla-Bell, F., Moisi, D. D., Ntemgwa, M., Frankel, F., Essex, M., \& Wainberg, M. A. (2006). HIV-1 subtype C viruses rapidly develop K65R resistance to tenofovir in cell culture. Aids, 20(9), F9-13.

Brun-Vezinet, F., Descamps, D., Ruffault, A., Masquelier, B., Calvez, V., Peytavin, G., Telles, F., Morand-Joubert, L., Meynard, J. L., Vray, M., \& Costagliola, D. (2003). Clinically relevant interpretation of genotype for resistance to abacavir. Aids, 17(12), 1795-1802.

Burton, D. R., \& Weiss, R. A. (2010). AIDS/HIV. A boost for HIV vaccine design. Science, 329(5993), 770-773.

Cabrera, C., Marfil, S., Garcia, E., Martinez-Picado, J., Bonjoch, A., Bofill, M., Moreno, S., Ribera, E., Domingo, P., Clotet, B., \& Ruiz, L. (2006). Genetic evolution of gp41 reveals a highly exclusive relationship between codons 36, 38 and 43 in gp41 under long-term enfuvirtide-containing salvage regimen. Aids, 20(16), 2075-2080.

Calarese, D. A., Scanlan, C. N., Zwick, M. B., Deechongkit, S., Mimura, Y., Kunert, R., Zhu, P., Wormald, M. R., Stanfield, R. L., Roux, K. H., Kelly, J. W., Rudd, P. M., Dwek, R. A., Katinger, H., Burton, D. R., \& Wilson, I. A. (2003). Antibody domain exchange is an immunological solution to carbohydrate cluster recognition. Science, 300(5628), 2065-2071.

Calazans, A., Brindeiro, R., Brindeiro, P., Verli, H., Arruda, M. B., Gonzalez, L. M., Guimaraes, J. A., Diaz, R. S., Antunes, O. A., \& Tanuri, A. (2005). Low accumulation of L90M in protease from subtype F HIV-1 with resistance to protease inhibitors is caused by the L89M polymorphism. J Infect Dis, 191(11), 1961-1970.

Cane, P. A., de Ruiter, A., Rice, P., Wiselka, M., Fox, R., \& Pillay, D. (2001). Resistanceassociated mutations in the human immunodeficiency virus type 1 subtype $c$ protease gene from treated and untreated patients in the United Kingdom. J Clin Microbiol, 39(7), 2652-2654.

Ceccherini-Silberstein, F., Erba, F., Gago, F., Bertoli, A., Forbici, F., Bellocchi, M. C., Gori, C., D'Arrigo, R., Marcon, L., Balotta, C., Antinori, A., Monforte, A. D., \& Perno, C. F. (2004). Identification of the minimal conserved structure of HIV-1 protease in the presence and absence of drug pressure. Aids, 18(12), F11-19.

Charpentier, C., Jenabian, M. A., Piketty, C., Karmochkine, M., Tisserand, P., Laureillard, D., Belec, L., Si-Mohamed, A., \& Weiss, L. (2011). Dynamics of enfuvirtide resistance mutations in enfuvirtide-experienced patients remaining in virological failure under salvage therapy. Scand J Infect Dis, 43(5), 373-379.

Chen, C. H., Chernis, G. A., Hoang, V. Q., \& Landgraf, R. (2003). Inhibition of heregulin signaling by an aptamer that preferentially binds to the oligomeric form of human epidermal growth factor receptor-3. Proc Natl Acad Sci U S A, 100(16), 9226-9231.

Choe, H., Farzan, M., Sun, Y., Sullivan, N., Rollins, B., Ponath, P. D., Wu, L., Mackay, C. R., LaRosa, G., Newman, W., Gerard, N., Gerard, C., \& Sodroski, J. (1996). The betachemokine receptors CCR3 and CCR5 facilitate infection by primary HIV-1 isolates. Cell, 85(7), 1135-1148. 
Clark, S. A., Shulman, N. S., Bosch, R. J., \& Mellors, J. W. (2006). Reverse transcriptase mutations 118I, 208Y, and 215Y cause HIV-1 hypersusceptibility to non-nucleoside reverse transcriptase inhibitors. Aids, 20(7), 981-984.

Cohen, C., Forzan, M., Sproat, B., Pantophlet, R., McGowan, I., Burton, D., \& James, W. (2008). An aptamer that neutralizes R5 strains of HIV-1 binds to core residues of gp120 in the CCR5 binding site. Virology, 381(1), 46-54.

Collman, R., Balliet, J. W., Gregory, S. A., Friedman, H., Kolson, D. L., Nathanson, N., \& Srinivasan, A. (1992). An infectious molecular clone of an unusual macrophagetropic and highly cytopathic strain of human immunodeficiency virus type $1 . J$ Virol, 66(12), 7517-7521.

Colonno, R., Rose, R., McLaren, C., Thiry, A., Parkin, N., \& Friborg, J. (2004). Identification of I50L as the signature atazanavir (ATV)-resistance mutation in treatment-naive HIV-1infected patients receiving ATV-containing regimens. J Infect Dis, 189(10), 1802-1810.

Connor, R. I., Sheridan, K. E., Ceradini, D., Choe, S., \& Landau, N. R. (1997). Change in coreceptor use coreceptor use correlates with disease progression in HIV-1-infected individuals. J Exp Med, 185(4), 621-628.

Cooper, D. A., Steigbigel, R. T., Gatell, J. M., Rockstroh, J. K., Katlama, C., Yeni, P., Lazzarin, A., Clotet, B., Kumar, P. N., Eron, J. E., Schechter, M., Markowitz, M., Loutfy, M. R., Lennox, J. L., Zhao, J., Chen, J., Ryan, D. M., Rhodes, R. R., Killar, J. A., Gilde, L. R., Strohmaier, K. M., Meibohm, A. R., Miller, M. D., Hazuda, D. J., Nessly, M. L., DiNubile, M. J., Isaacs, R. D., Teppler, H., \& Nguyen, B. Y. (2008). Subgroup and resistance analyses of raltegravir for resistant HIV-1 infection. N Engl J Med, 359(4), 355-365.

Corti, D., Langedijk, J. P., Hinz, A., Seaman, M. S., Vanzetta, F., Fernandez-Rodriguez, B. M., Silacci, C., Pinna, D., Jarrossay, D., Balla-Jhagjhoorsingh, S., Willems, B., Zekveld, M. J., Dreja, H., O'Sullivan, E., Pade, C., Orkin, C., Jeffs, S. A., Montefiori, D. C., Davis, D., Weissenhorn, W., McKnight, A., Heeney, J. L., Sallusto, F., Sattentau, Q. J., Weiss, R. A., \& Lanzavecchia, A. (2010). Analysis of memory B cell responses and isolation of novel monoclonal antibodies with neutralizing breadth from HIV-1infected individuals. PLoS One, 5(1), e8805.

Cotton, M. F., Ikle, D. N., Rapaport, E. L., Marschner, S., Tseng, P. O., Kurrle, R., \& Finkel, T. H. (1997). Apoptosis of CD4+ and CD8+ T cells isolated immediately ex vivo correlates with disease severity in human immunodeficiency virus type 1 infection. Pediatr Res, 42(5), 656-664.

Cozzi-Lepri, A., Ruiz, L., Loveday, C., Phillips, A. N., Clotet, B., Reiss, P., Ledergerber, B., Holkmann, C., Staszewski, S., \& Lundgren, J. D. (2005). Thymidine analogue mutation profiles: factors associated with acquiring specific profiles and their impact on the virological response to therapy. Antivir Ther, 10(7), 791-802.

Dandache, S., Sevigny, G., Yelle, J., Stranix, B. R., Parkin, N., Schapiro, J. M., Wainberg, M. A., \& Wu, J. J. (2007). In vitro antiviral activity and cross-resistance profile of PL100, a novel protease inhibitor of human immunodeficiency virus type 1 . Antimicrob Agents Chemother, 51(11), 4036-4043.

Das, K., Bauman, J. D., Clark, A. D., Jr., Frenkel, Y. V., Lewi, P. J., Shatkin, A. J., Hughes, S. H., \& Arnold, E. (2008). High-resolution structures of HIV-1 reverse transcriptase/TMC278 complexes: strategic flexibility explains potency against resistance mutations. Proc Natl Acad Sci U S A, 105(5), 1466-1471.

Das, K., Clark, A. D., Jr., Lewi, P. J., Heeres, J., De Jonge, M. R., Koymans, L. M., Vinkers, H. M., Daeyaert, F., Ludovici, D. W., Kukla, M. J., De Corte, B., Kavash, R. W., Ho, C. Y., Ye, H., Lichtenstein, M. A., Andries, K., Pauwels, R., De Bethune, M. P., Boyer, 
P. L., Clark, P., Hughes, S. H., Janssen, P. A., \& Arnold, E. (2004). Roles of conformational and positional adaptability in structure-based design of TMC125R165335 (etravirine) and related non-nucleoside reverse transcriptase inhibitors that are highly potent and effective against wild-type and drug-resistant HIV-1 variants. J Med Chem, 47(10), 2550-2560.

Das, K., Ding, J., Hsiou, Y., Clark, A. D., Jr., Moereels, H., Koymans, L., Andries, K., Pauwels, R., Janssen, P. A., Boyer, P. L., Clark, P., Smith, R. H., Jr., Kroeger Smith, M. B., Michejda, C. J., Hughes, S. H., \& Arnold, E. (1996). Crystal structures of 8-Cl and 9-Cl TIBO complexed with wild-type HIV-1 RT and 8-Cl TIBO complexed with the Tyr181Cys HIV-1 RT drug-resistant mutant. J Mol Biol, 264(5), 1085-1100.

De Luca, A., Di Giambenedetto, S., Romano, L., Gonnelli, A., Corsi, P., Baldari, M., Di Pietro, M., Menzo, S., Francisci, D., Almi, P., \& Zazzi, M. (2006). Frequency and treatmentrelated predictors of thymidine-analogue mutation patterns in HIV-1 isolates after unsuccessful antiretroviral therapy. J Infect Dis, 193(9), 1219-1222.

De Luca, A., Giambenedetto, S. D., Trotta, M. P., Colafigli, M., Prosperi, M., Ruiz, L., Baxter, J., Clevenbergh, P., Cauda, R., Perno, C. F., \& Antinori, A. (2007). Improved interpretation of genotypic changes in the HIV-1 reverse transcriptase coding region that determine the virological response to didanosine. J Infect Dis, 196(11), 1645-1653.

Deeks, S. G., Lu, J., Hoh, R., Neilands, T. B., Beatty, G., Huang, W., Liegler, T., Hunt, P., Martin, J. N., \& Kuritzkes, D. R. (2007). Interruption of enfuvirtide in HIV-1 infected adults with incomplete viral suppression on an enfuvirtide-based regimen. J Infect Dis, 195(3), 387-391.

Deforche, K., Camacho, R., Grossman, Z., Silander, T., Soares, M. A., Moreau, Y., Shafer, R. W., Van Laethem, K., Carvalho, A. P., Wynhoven, B., Cane, P., Snoeck, J., Clarke, J., Sirivichayakul, S., Ariyoshi, K., Holguin, A., Rudich, H., Rodrigues, R., Bouzas, M. B., Cahn, P., Brigido, L. F., Soriano, V., Sugiura, W., Phanuphak, P., Morris, L., Weber, J., Pillay, D., Tanuri, A., Harrigan, P. R., Shapiro, J. M., Katzenstein, D. A., Kantor, R., \& Vandamme, A. M. (2007). Bayesian network analysis of resistance pathways against HIV-1 protease inhibitors. Infect Genet Evol, 7(3), 382-390.

Deforche, K., Silander, T., Camacho, R., Grossman, Z., Soares, M. A., Van Laethem, K., Kantor, R., Moreau, Y., \& Vandamme, A. M. (2006). Analysis of HIV-1 pol sequences using Bayesian Networks: implications for drug resistance. Bioinformatics, 22(24), 2975-2979.

Delaugerre, C., Rohban, R., Simon, A., Mouroux, M., Tricot, C., Agher, R., Huraux, J. M., Katlama, C., \& Calvez, V. (2001). Resistance profile and cross-resistance of HIV-1 among patients failing a non-nucleoside reverse transcriptase inhibitor-containing regimen. J Med Virol, 65(3), 445-448.

Delelis, O., Thierry, S., Subra, F., Simon, F., Malet, I., Alloui, C., Sayon, S., Calvez, V., Deprez, E., Marcelin, A. G., Tchertanov, L., \& Mouscadet, J. F. (2011). Impact of Y143 HIV-1 integrase mutations on resistance to raltegravir in vitro and in vivo. Antimicrob Agents Chemother, 54(1), 491-501.

Demeter, L. M., DeGruttola, V., Lustgarten, S., Bettendorf, D., Fischl, M., Eshleman, S., Spreen, W., Nguyen, B. Y., Koval, C. E., Eron, J. J., Hammer, S., \& Squires, K. (2008). Association of efavirenz hypersusceptibility with virologic response in ACTG 368, a randomized trial of abacavir (ABC) in combination with efavirenz (EFV) and indinavir (IDV) in HIV-infected subjects with prior nucleoside analog experience. HIV Clin Trials, 9(1), 11-25.

Deng, H., Liu, R., Ellmeier, W., Choe, S., Unutmaz, D., Burkhart, M., Di Marzio, P., Marmon, S., Sutton, R. E., Hill, C. M., Davis, C. B., Peiper, S. C., Schall, T. J., Littman, D. R., \& 
Landau, N. R. (1996). Identification of a major co-receptor for primary isolates of HIV-1 [see comments]. Nature, 381(6584), 661-666.

Descamps, D., Ait-Khaled, M., Craig, C., Delarue, S., Damond, F., Collin, G., \& BrunVezinet, F. (2006). Rare selection of the K65R mutation in antiretroviral-naive patients failing a first-line abacavir/ lamivudine-containing HAART regimen. Antivir Ther, 11(6), 701-705.

Dey, A. K., Khati, M., Tang, M., Wyatt, R., Lea, S. M., \& James, W. (2005). An aptamer that neutralizes R5 strains of human immunodeficiency virus type 1 blocks gp120-CCR5 interaction. J Virol, 79(21), 13806-13810.

di Marzo Veronese, F., Copeland, T. D., DeVico, A. L., Rahman, R., Oroszlan, S., Gallo, R. C., \& Sarngadharan, M. G. (1986). Characterization of highly immunogenic p66/p51 as the reverse transcriptase of HTLV-III/LAV. Science, 231(4743), 1289-1291.

Doranz, B. J., Lu, Z. H., Rucker, J., Zhang, T. Y., Sharron, M., Cen, Y. H., Wang, Z. X., Guo, H. H., Du, J. G., Accavitti, M. A., Doms, R. W., \& Peiper, S. C. (1997). Two distinct CCR5 domains can mediate coreceptor usage by human immunodeficiency virus type 1. J Virol, 71(9), 6305-6314.

Doranz, B. J., Rucker, J., Yi, Y., Smyth, R. J., Samson, M., Peiper, S. C., Parmentier, M., Collman, R. G., \& Doms, R. W. (1996). A dual-tropic primary HIV-1 isolate that uses fusin and the beta- chemokine receptors CKR-5, CKR-3, and CKR-2b as fusion cofactors. Cell, 85(7), 1149-1158.

Doualla-Bell, F., Avalos, A., Brenner, B., Gaolathe, T., Mine, M., Gaseitsiwe, S., Oliveira, M., Moisi, D., Ndwapi, N., Moffat, H., Essex, M., \& Wainberg, M. A. (2006). High prevalence of the K65R mutation in human immunodeficiency virus type 1 subtype $\mathrm{C}$ isolates from infected patients in Botswana treated with didanosine-based regimens. Antimicrob Agents Chemother, 50(12), 4182-4185.

Dragic, T., Litwin, V., Allaway, G. P., Martin, S. R., Huang, Y., Nagashima, K. A., Cayanan, C., Maddon, P. J., Koup, R. A., Moore, J. P., \& Paxton, W. A. (1996). HIV-1 entry into CD4+ cells is mediated by the chemokine receptor CC- CKR-5 [see comments]. Nature, 381(6584), 667-673.

Dragic, T., Trkola, A., Thompson, D. A., Cormier, E. G., Kajumo, F. A., Maxwell, E., Lin, S. W., Ying, W., Smith, S. O., Sakmar, T. P., \& Moore, J. P. (2000). A binding pocket for a small molecule inhibitor of HIV-1 entry within the transmembrane helices of CCR5. Proc Natl Acad Sci U S A, 97(10), 5639-5644.

Eron, J., Jr., Yeni, P., Gathe, J., Jr., Estrada, V., DeJesus, E., Staszewski, S., Lackey, P., Katlama, C., Young, B., Yau, L., Sutherland-Phillips, D., Wannamaker, P., Vavro, C., Patel, L., Yeo, J., \& Shaefer, M. (2006). The KLEAN study of fosamprenavirritonavir versus lopinavir-ritonavir, each in combination with abacavir-lamivudine, for initial treatment of HIV infection over 48 weeks: a randomised non-inferiority trial. Lancet, 368(9534), 476-482.

Eron, J. J., Jr., Bosch, R. J., Bettendorf, D., Petch, L., Fiscus, S., \& Frank, I. (2007). The effect of lamivudine therapy and $\mathrm{M} 184 \mathrm{~V}$ on the antiretroviral activity of didanosine. $J$ Acquir Immune Defic Syndr, 45(2), 249-251.

Euler, Z., Bunnik, E. M., Burger, J. A., Boeser-Nunnink, B. D., Grijsen, M. L., Prins, J. M., \& Schuitemaker, H. (2011). Activity of broadly neutralizing antibodies, including PG9, PG16, and VRC01, against recently transmitted subtype B HIV-1 variants from early and late in the epidemic. J Virol, 85(14), 7236-7245.

Eyetech Study Group (2002). Preclinical and phase 1A clinical evaluation of an anti-VEGF pegylated aptamer (EYE001) for the treatment of exudative age-related macular degeneration. Retina, 22(2), 143-152. 
Eyetech Study Group (2003). Anti-vascular endothelial growth factor therapy for subfoveal choroidal neovascularization secondary to age-related macular degeneration: phase II study results. Ophthalmology, 110(5), 979-986.

FDA (2007). FDA approves raltegravir tablets. AIDS Patient Care STDS, 21(11), 889.

Fischl, M. A., Richman, D. D., Grieco, M. H., Gottlieb, M. S., Volberding, P. A., Laskin, O. L., Leedom, J. M., Groopman, J. E., Mildvan, D., Schooley, R. T., \& et al. (1987). The efficacy of azidothymidine (AZT) in the treatment of patients with AIDS and AIDSrelated complex. A double-blind, placebo-controlled trial. N Engl J Med, 317(4), 185191.

Frater, A. J., Chaput, C. C., Beddows, S., Weber, J. N., \& McClure, M. O. (2001). Simple detection of point mutations associated with HIV-1 drug resistance. J Virol Methods, 93(1-2), 145-156.

Frey, G., Peng, H., Rits-Volloch, S., Morelli, M., Cheng, Y., \& Chen, B. (2008). A fusionintermediate state of HIV-1 gp41 targeted by broadly neutralizing antibodies. Proc Natl Acad Sci U S A, 105(10), 3739-3744.

Friend, J., Parkin, N., Liegler, T., Martin, J. N., \& Deeks, S. G. (2004). Isolated lopinavir resistance after virological rebound of a ritonavir/lopinavir-based regimen. Aids, 18(14), 1965-1966.

Gallant, J. E., DeJesus, E., Arribas, J. R., Pozniak, A. L., Gazzard, B., Campo, R. E., Lu, B., McColl, D., Chuck, S., Enejosa, J., Toole, J. J., \& Cheng, A. K. (2006). Tenofovir DF, emtricitabine, and efavirenz vs. zidovudine, lamivudine, and efavirenz for HIV. N Engl J Med, 354(3), 251-260.

Gallant, J. E., Staszewski, S., Pozniak, A. L., DeJesus, E., Suleiman, J. M., Miller, M. D., Coakley, D. F., Lu, B., Toole, J. J., \& Cheng, A. K. (2004). Efficacy and safety of tenofovir DF vs stavudine in combination therapy in antiretroviral-naive patients: a 3-year randomized trial. Jama, 292(2), 191-201.

Gao, H. Q., Boyer, P. L., Sarafianos, S. G., Arnold, E., \& Hughes, S. H. (2000). The role of steric hindrance in 3TC resistance of human immunodeficiency virus type-1 reverse transcriptase. J Mol Biol, 300(2), 403-418.

Garg, H., Joshi, A., Freed, E. O., \& Blumenthal, R. (2007). Site-specific mutations in HIV-1 gp41 reveal a correlation between HIV-1-mediated bystander apoptosis and fusion/hemifusion. J Biol Chem, 282(23), 16899-16906.

Gilead Sciences (2008). Phase III trial begins for elvitegravir. AIDS Patient Care STDS, 22(9), 762-763.

Gonzales, M. J., Wu, T. D., Taylor, J., Belitskaya, I., Kantor, R., Israelski, D., Chou, S., Zolopa, A. R., Fessel, W. J., \& Shafer, R. W. (2003). Extended spectrum of HIV-1 reverse transcriptase mutations in patients receiving multiple nucleoside analog inhibitors. Aids, 17(6), 791-799.

Gonzalez, L. M., Brindeiro, R. M., Aguiar, R. S., Pereira, H. S., Abreu, C. M., Soares, M. A., \& Tanuri, A. (2004). Impact of nelfinavir resistance mutations on in vitro phenotype, fitness, and replication capacity of human immunodeficiency virus type 1 with subtype B and C proteases. Antimicrob Agents Chemother, 48(9), 3552-3555.

Gougeon, M. L., \& Montagnier, L. (1993). Apoptosis in AIDS. Science, 260(5112), 1269-1270.

Gray, E. S., Meyers, T., Gray, G., Montefiori, D. C., \& Morris, L. (2006). Insensitivity of paediatric HIV-1 subtype $\mathrm{C}$ viruses to broadly neutralising monoclonal antibodies raised against subtype B. PLoS Med, 3(7), e255.

Gray, E. S., Moore, P. L., Bibollet-Ruche, F., Li, H., Decker, J. M., Meyers, T., Shaw, G. M., \& Morris, L. (2008). 4E10-resistant variants in a human immunodeficiency virus type 
1 subtype C-infected individual with an anti-membrane-proximal external regionneutralizing antibody response. J Virol, 82(5), 2367-2375.

Green, L. S., Jellinek, D., Bell, C., Beebe, L. A., Feistner, B. D., Gill, S. C., Jucker, F. M., \& Janjic, N. (1995). Nuclease-resistant nucleic acid ligands to vascular permeability factor/vascular endothelial growth factor. Chem Biol, 2(10), 683-695.

Grossman, Z., Paxinos, E. E., Averbuch, D., Maayan, S., Parkin, N. T., Engelhard, D., Lorber, M., Istomin, V., Shaked, Y., Mendelson, E., Ram, D., Petropoulos, C. J., \& Schapiro, J. M. (2004). Mutation D30N is not preferentially selected by human immunodeficiency virus type 1 subtype $C$ in the development of resistance to nelfinavir. Antimicrob Agents Chemother, 48(6), 2159-2165.

Harrigan, P. R., Stone, C., Griffin, P., Najera, I., Bloor, S., Kemp, S., Tisdale, M., \& Larder, B. (2000). Resistance profile of the human immunodeficiency virus type 1 reverse transcriptase inhibitor abacavir (1592U89) after monotherapy and combination therapy. CNA2001 Investigative Group. J Infect Dis, 181(3), 912-920.

Hartley, O., Klasse, P. J., Sattentau, Q. J., \& Moore, J. P. (2005). V3: HIV's switch-hitter. AIDS Res Hum Retroviruses, 21(2), 171-189.

Hawkins, C. A., Chaplin, B., Idoko, J., Ekong, E., Adewole, I., Gashau, W., Murphy, R. L., \& Kanki, P. (2009). Clinical and genotypic findings in HIV-infected patients with the K65R mutation failing first-line antiretroviral therapy in Nigeria. J Acquir Immune Defic Syndr, 52(2), 228-234.

Held, D. M., Kissel, J. D., Patterson, J. T., Nickens, D. G., \& Burke, D. H. (2006). HIV-1 inactivation by nucleic acid aptamers. Front Biosci, 11, 89-112.

Herbein, G., Mahlknecht, U., Batliwalla, F., Gregersen, P., Pappas, T., Butler, J., O'Brien, W. A., \& Verdin, E. (1998). Apoptosis of CD8+ T cells is mediated by macrophages through interaction of HIV gp120 with chemokine receptor CXCR4. Nature, 395(6698), 189-194.

Ho, D. D., McKeating, J. A., Li, X. L., Moudgil, T., Daar, E. S., Sun, N. C., \& Robinson, J. E. (1991). Conformational epitope on gp120 important in CD4 binding and human immunodeficiency virus type 1 neutralization identified by a human monoclonal antibody. J Virol, 65(1), 489-493.

Hoffman, N. G., Schiffer, C. A., \& Swanstrom, R. (2003). Covariation of amino acid positions in HIV-1 protease. Virology, 314(2), 536-548.

Hombrouck, A., Voet, A., Van Remoortel, B., Desadeleer, C., De Maeyer, M., Debyser, Z., \& Witvrouw, M. (2008). Mutations in human immunodeficiency virus type 1 integrase confer resistance to the naphthyridine L-870,810 and cross-resistance to the clinical trial drug GS-9137. Antimicrob Agents Chemother, 52(6), 2069-2078.

Howard, O. M., Shirakawa, A. K., Turpin, J. A., Maynard, A., Tobin, G. J., Carrington, M., Oppenheim, J. J., \& Dean, M. (1999). Naturally occurring CCR5 extracellular and transmembrane domain variants affect HIV-1 Co-receptor and ligand binding function. J Biol Chem, 274(23), 16228-16234.

Hsiou, Y., Ding, J., Das, K., Clark, A. D., Jr., Boyer, P. L., Lewi, P., Janssen, P. A., Kleim, J. P., Rosner, M., Hughes, S. H., \& Arnold, E. (2001). The Lys103Asn mutation of HIV-1 RT: a novel mechanism of drug resistance. J Mol Biol, 309(2), 437-445.

Huang, K. H., Goedhals, D., Carlson, J. M., Brockman, M. A., Mishra, S., Brumme, Z. L., Hickling, S., Tang, C. S., Miura, T., Seebregts, C., Heckerman, D., Ndung'u, T., Walker, B., Klenerman, P., Steyn, D., Goulder, P., Phillips, R., van Vuuren, C., \& Frater, J. (2011). Progression to AIDS in South Africa is associated with both reverting and compensatory viral mutations. PLoS One, 6(4), e19018. 
Huang, W., Eshleman, S. H., Toma, J., Fransen, S., Stawiski, E., Paxinos, E. E., Whitcomb, J. M., Young, A. M., Donnell, D., Mmiro, F., Musoke, P., Guay, L. A., Jackson, J. B., Parkin, N. T., \& Petropoulos, C. J. (2007). Coreceptor tropism in human immunodeficiency virus type 1 subtype D: high prevalence of CXCR4 tropism and heterogeneous composition of viral populations. J Virol, 81(15), 7885-7893.

Huang, W., Toma, J., Fransen, S., Stawiski, E., Reeves, J. D., Whitcomb, J. M., Parkin, N., \& Petropoulos, C. J. (2008). Coreceptor tropism can be influenced by amino acid substitutions in the gp41 transmembrane subunit of human immunodeficiency virus type 1 envelope protein. J Virol, 82(11), 5584-5593.

Ishikawa, H., Sasaki, M., Noda, S., \& Koga, Y. (1998). Apoptosis induction by the binding of the carboxyl terminus of human immunodeficiency virus type 1 gp160 to calmodulin. J Virol, 72(8), 6574-6580.

Janssen, P. A., Lewi, P. J., Arnold, E., Daeyaert, F., de Jonge, M., Heeres, J., Koymans, L., Vinkers, M., Guillemont, J., Pasquier, E., Kukla, M., Ludovici, D., Andries, K., de Bethune, M. P., Pauwels, R., Das, K., Clark, A. D., Jr., Frenkel, Y. V., Hughes, S. H., Medaer, B., De Knaep, F., Bohets, H., De Clerck, F., Lampo, A., Williams, P., \& Stoffels, P. (2005). In search of a novel anti-HIV drug: multidisciplinary coordination in the discovery of 4-[[4-[[4-[(1E)-2-cyanoethenyl]-2,6-dimethylphenyl]amino]-2pyrimidinyl]amino]benzonitrile (R278474, rilpivirine). J Med Chem, 48(6), 1901-1909.

Jensen, M. A., \& van 't Wout, A. B. (2003). Predicting HIV-1 coreceptor usage with sequence analysis. AIDS Rev, 5(2), 104-112.

Johnson, A. A., Santos, W., Pais, G. C., Marchand, C., Amin, R., Burke, T. R., Jr., Verdine, G., \& Pommier, Y. (2006). Integration requires a specific interaction of the donor DNA terminal 5'-cytosine with glutamine 148 of the HIV-1 integrase flexible loop. J Biol Chem, 281(1), 461-467.

Johnson, V. A., Brun-Vezinet, F., Clotet, B., Gunthard, H. F., Kuritzkes, D. R., Pillay, D., Schapiro, J. M., \& Richman, D. D. (2010). Update of the drug resistance mutations in HIV-1: December 2010. Top HIV Med, 18(5), 156-163.

Johnston, E., Winters, M. A., Rhee, S. Y., Merigan, T. C., Schiffer, C. A., \& Shafer, R. W. (2004). Association of a novel human immunodeficiency virus type 1 protease substrate cleft mutation, L23I, with protease inhibitor therapy and in vitro drug resistance. Antimicrob Agents Chemother, 48(12), 4864-4868.

Joshi, A., Nyakeriga, A., Ravi, R., \& Garg, H. (2011). HIV ENV glycoprotein mediated bystander apoptosis is dependent on CCR5 cell surface expression levels as well as env fusogenic activity. J Biol Chem.

Joubert, M. K., Kinsley, N., Capovilla, A., Sewell, B. T., Jaffer, M. A., \& Khati, M. (2010). A modeled structure of an aptamer-gp120 complex provides insight into the mechanism of HIV-1 neutralization. Biochemistry, 49(28), 5880-5890.

Kagan, R. M., Shenderovich, M. D., Heseltine, P. N., \& Ramnarayan, K. (2005). Structural analysis of an HIV-1 protease I47A mutant resistant to the protease inhibitor lopinavir. Protein Sci, 14(7), 1870-1878.

Kalia, V., Sarkar, S., Gupta, P., \& Montelaro, R. C. (2005). Antibody neutralization escape mediated by point mutations in the intracytoplasmic tail of human immunodeficiency virus type 1 gp41. J Virol, 79(4), 2097-2107.

Kantor, R., Katzenstein, D. A., Efron, B., Carvalho, A. P., Wynhoven, B., Cane, P., Clarke, J., Sirivichayakul, S., Soares, M. A., Snoeck, J., Pillay, C., Rudich, H., Rodrigues, R., Holguin, A., Ariyoshi, K., Bouzas, M. B., Cahn, P., Sugiura, W., Soriano, V., Brigido, L. F., Grossman, Z., Morris, L., Vandamme, A. M., Tanuri, A., Phanuphak, P., Weber, J. N., Pillay, D., Harrigan, P. R., Camacho, R., Schapiro, J. M., \& Shafer, R. W. (2005). 
Impact of HIV-1 subtype and antiretroviral therapy on protease and reverse transcriptase genotype: results of a global collaboration. PLoS Med, 2(4), e112.

Khati, M. (2010). The future of aptamers in medicine. J Clin Pathol, 63(6), 480-487.

Khati, M., Schuman, M., Ibrahim, J., Sattentau, Q., Gordon, S., \& James, W. (2003). Neutralization of infectivity of diverse R5 clinical isolates of human immunodeficiency virus type 1 by gp120-binding 2'F-RNA aptamers. J Virol, 77(23), 12692-12698.

Kilby, J. M., Hopkins, S., Venetta, T. M., DiMassimo, B., Cloud, G. A., Lee, J. Y., Alldredge, L., Hunter, E., Lambert, D., Bolognesi, D., Matthews, T., Johnson, M. R., Nowak, M. A., Shaw, G. M., \& Saag, M. S. (1998). Potent suppression of HIV-1 replication in humans by T-20, a peptide inhibitor of gp41-mediated virus entry. Nat Med, 4(11), 1302-1307.

Kim, Y. M., Choi, K. H., Jang, Y. J., Yu, J., \& Jeong, S. (2003). Specific modulation of the antiDNA autoantibody-nucleic acids interaction by the high affinity RNA aptamer. Biochem Biophys Res Commun, 300(2), 516-523.

Kohlstaedt, L. A., Wang, J., Friedman, J. M., Rice, P. A., \& Steitz, T. A. (1992a). Crystal structure at $3.5 \mathrm{~A}$ resolution of HIV-1 reverse transcriptase complexed with an inhibitor. Science, 256(5065), 1783-1790.

Kohlstaedt, L. A., Wang, J., Friedman, J. M., Rice, P. A., \& Steitz, T. A. (1992b). Crystal structure at $3.5 \mathrm{~A}$ resolution of HIV-1 reverse transcriptase complexed with an inhibitor. Science, 256(5065), 1783-1790.

Kwong, P. D., Wyatt, R., Robinson, J., Sweet, R. W., Sodroski, J., \& Hendrickson, W. A. (1998a). Structure of an HIV gp120 envelope glycoprotein in complex with the CD4 receptor and a neutralizing human antibody. Nature, 393(6686), 648-659.

Kwong, P. D., Wyatt, R., Robinson, J., Sweet, R. W., Sodroski, J., \& Hendrickson, W. A. (1998b). Structure of an HIV gp120 envelope glycoprotein in complex with the CD4 receptor and a neutralizing human antibody [see comments]. Nature, 393(6686), 648-659.

Lanier, E. R., Ait-Khaled, M., Scott, J., Stone, C., Melby, T., Sturge, G., St Clair, M., Steel, H., Hetherington, S., Pearce, G., Spreen, W., \& Lafon, S. (2004a). Antiviral efficacy of abacavir in antiretroviral therapy-experienced adults harbouring HIV-1 with specific patterns of resistance to nucleoside reverse transcriptase inhibitors. Antivir Ther, 9(1), 37-45.

Lanier, E. R., Givens, N., Stone, C., Griffin, P., Gibb, D., Walker, S., Tisdale, M., Irlbeck, D., Underwood, M., St Clair, M., \& Ait-Khaled, M. (2004b). Effect of concurrent zidovudine use on the resistance pathway selected by abacavir-containing regimens. HIV Med, 5(6), 394-399.

Lataillade, M., Chiarella, J., \& Kozal, M. J. (2007). Natural polymorphism of the HIV-1 integrase gene and mutations associated with integrase inhibitor resistance. Antivir Ther, 12(4), 563-570.

Lazzarin, A., Campbell, T., Clotet, B., Johnson, M., Katlama, C., Moll, A., Towner, W., Trottier, B., Peeters, M., Vingerhoets, J., de Smedt, G., Baeten, B., Beets, G., Sinha, R., \& Woodfall, B. (2007). Efficacy and safety of TMC125 (etravirine) in treatmentexperienced HIV-1-infected patients in DUET-2: 24-week results from a randomised, double-blind, placebo-controlled trial. Lancet, 370(9581), 39-48.

Li, C. J., Friedman, D. J., Wang, C., Metelev, V., \& Pardee, A. B. (1995). Induction of apoptosis in uninfected lymphocytes by HIV-1 Tat protein. Science, 268(5209), 429-431.

Li, Y., O'Dell, S., Walker, L. M., Wu, X., Guenaga, J., Feng, Y., Schmidt, S. D., McKee, K., Louder, M. K., Ledgerwood, J. E., Graham, B. S., Haynes, B. F., Burton, D. R., Wyatt, R. T., \& Mascola, J. R. (2011). Mechanism of neutralization by the broadly neutralizing HIV-1 monoclonal antibody VRC01. J Virol, 85(17), 8954-8967. 
Liu, Y., Sun, Q. A., Chen, Q., Lee, T. H., Huang, Y., Wetsel, W. C., Michelotti, G. A., Sullenger, B. A., \& Zhang, X. (2009). Targeting inhibition of GluR1 Ser845 phosphorylation with an RNA aptamer that blocks AMPA receptor trafficking. $J$ Neurochem, 108(1), 147-157.

Low, A. J., Dong, W., Chan, D., Sing, T., Swanstrom, R., Jensen, M., Pillai, S., Good, B., \& Harrigan, P. R. (2007). Current V3 genotyping algorithms are inadequate for predicting X4 co-receptor usage in clinical isolates. Aids, 21(14), F17-24.

Lu, J., Deeks, S. G., Hoh, R., Beatty, G., Kuritzkes, B. A., Martin, J. N., \& Kuritzkes, D. R. (2006). Rapid emergence of enfuvirtide resistance in HIV-1-infected patients: results of a clonal analysis. J Acquir Immune Defic Syndr, 43(1), 60-64.

Lu, J., Sista, P., Giguel, F., Greenberg, M., \& Kuritzkes, D. R. (2004). Relative replicative fitness of human immunodeficiency virus type 1 mutants resistant to enfuvirtide (T-20). J Virol, 78(9), 4628-4637.

Luo, X. M., Lei, M. Y., Feidi, R. A., West, A. P., Jr., Balazs, A. B., Bjorkman, P. J., Yang, L., \& Baltimore, D. (2011). Dimeric 2 G12 as a potent protection against HIV-1. PLoS Pathog, 6(12), e1001225.

Lupold, S. E., Hicke, B. J., Lin, Y., \& Coffey, D. S. (2002). Identification and characterization of nuclease-stabilized RNA molecules that bind human prostate cancer cells via the prostate-specific membrane antigen. Cancer Res, 62(14), 4029-4033.

Madruga, J. V., Cahn, P., Grinsztejn, B., Haubrich, R., Lalezari, J., Mills, A., Pialoux, G., Wilkin, T., Peeters, M., Vingerhoets, J., de Smedt, G., Leopold, L., Trefiglio, R., \& Woodfall, B. (2007). Efficacy and safety of TMC125 (etravirine) in treatmentexperienced HIV-1-infected patients in DUET-1: 24-week results from a randomised, double-blind, placebo-controlled trial. Lancet, 370(9581), 29-38.

Malet, I., Delelis, O., Valantin, M. A., Montes, B., Soulie, C., Wirden, M., Tchertanov, L., Peytavin, G., Reynes, J., Mouscadet, J. F., Katlama, C., Calvez, V., \& Marcelin, A. G. (2008). Mutations associated with failure of raltegravir treatment affect integrase sensitivity to the inhibitor in vitro. Antimicrob Agents Chemother, 52(4), 1351-1358.

Mammano, F., Petit, C., \& Clavel, F. (1998). Resistance-associated loss of viral fitness in human immunodeficiency virus type 1: phenotypic analysis of protease and gag coevolution in protease inhibitor-treated patients. J Virol, 72(9), 7632-7637.

Marcelin, A. G., Dalban, C., Peytavin, G., Lamotte, C., Agher, R., Delaugerre, C., Wirden, M., Conan, F., Dantin, S., Katlama, C., Costagliola, D., \& Calvez, V. (2004a). Clinically relevant interpretation of genotype and relationship to plasma drug concentrations for resistance to saquinavir-ritonavir in human immunodeficiency virus type 1 protease inhibitor-experienced patients. Antimicrob Agents Chemother, 48(12), 46874692.

Marcelin, A. G., Delaugerre, C., Wirden, M., Viegas, P., Simon, A., Katlama, C., \& Calvez, V. (2004b). Thymidine analogue reverse transcriptase inhibitors resistance mutations profiles and association to other nucleoside reverse transcriptase inhibitors resistance mutations observed in the context of virological failure. J Med Virol, 72(1), 162-165.

Marcelin, A. G., Flandre, P., de Mendoza, C., Roquebert, B., Peytavin, G., Valer, L., Wirden, M., Abbas, S., Katlama, C., Soriano, V., \& Calvez, V. (2007). Clinical validation of saquinavir/ritonavir genotypic resistance score in protease-inhibitor-experienced patients. Antivir Ther, 12(2), 247-252.

Marcelin, A. G., Flandre, P., Pavie, J., Schmidely, N., Wirden, M., Lada, O., Chiche, D., Molina, J. M., \& Calvez, V. (2005). Clinically relevant genotype interpretation of resistance to didanosine. Antimicrob Agents Chemother, 49(5), 1739-1744. 
Marcelin, A. G., Reynes, J., Yerly, S., Ktorza, N., Segondy, M., Piot, J. C., Delfraissy, J. F., Kaiser, L., Perrin, L., Katlama, C., \& Calvez, V. (2004c). Characterization of genotypic determinants in HR-1 and HR-2 gp41 domains in individuals with persistent HIV viraemia under T-20. Aids, 18(9), 1340-1342.

Margot, N. A., Lu, B., Cheng, A., \& Miller, M. D. (2006). Resistance development over 144 weeks in treatment-naive patients receiving tenofovir disoproxil fumarate or stavudine with lamivudine and efavirenz in Study 903. HIV Med, 7(7), 442-450.

Martinez-Picado, J., Savara, A. V., Sutton, L., \& D'Aquila, R. T. (1999). Replicative fitness of protease inhibitor-resistant mutants of human immunodeficiency virus type 1 . J Virol, 73(5), 3744-3752.

Masquelier, B., Assoumou, K. L., Descamps, D., Bocket, L., Cottalorda, J., Ruffault, A., Marcelin, A. G., Morand-Joubert, L., Tamalet, C., Charpentier, C., Peytavin, G., Antoun, Z., Brun-Vezinet, F., \& Costagliola, D. (2008). Clinically validated mutation scores for HIV-1 resistance to fosamprenavir/ritonavir. J Antimicrob Chemother, 61(6), 1362-1368.

McNicholas, P. M., Mann, P. A., Wojcik, L., Phd, P. Q., Lee, E., McCarthy, M., Shen, J., Black, T. A., \& Strizki, J. M. (2011). Mapping and characterization of vicriviroc resistance mutations from HIV-1 isolated from treatment-experienced subjects enrolled in a phase II study (VICTOR-E1). J Acquir Immune Defic Syndr, 56(3), 222-229.

Melby, T., Sista, P., DeMasi, R., Kirkland, T., Roberts, N., Salgo, M., Heilek-Snyder, G., Cammack, N., Matthews, T. J., \& Greenberg, M. L. (2006). Characterization of envelope glycoprotein gp41 genotype and phenotypic susceptibility to enfuvirtide at baseline and on treatment in the phase III clinical trials TORO-1 and TORO-2. AIDS Res Hum Retroviruses, 22(5), 375-385.

Menzo, S., Castagna, A., Monachetti, A., Hasson, H., Danise, A., Carini, E., Bagnarelli, P., Lazzarin, A., \& Clementi, M. (2004). Genotype and phenotype patterns of human immunodeficiency virus type 1 resistance to enfuvirtide during long-term treatment. Antimicrob Agents Chemother, 48(9), 3253-3259.

Meyer, P. R., Matsuura, S. E., Mian, A. M., So, A. G., \& Scott, W. A. (1999). A mechanism of AZT resistance: an increase in nucleotide-dependent primer unblocking by mutant HIV-1 reverse transcriptase. Mol Cell, 4(1), 35-43.

Meyer, P. R., Matsuura, S. E., So, A. G., \& Scott, W. A. (1998). Unblocking of chainterminated primer by HIV-1 reverse transcriptase through a nucleotide-dependent mechanism. Proc Natl Acad Sci U S A, 95(23), 13471-13476.

Mi, Z., Guo, H., Russell, M. B., Liu, Y., Sullenger, B. A., \& Kuo, P. C. (2009). RNA aptamer blockade of osteopontin inhibits growth and metastasis of MDA-MB231 breast cancer cells. Mol Ther, 17(1), 153-161.

Micoli, K. J., Mamaeva, O., Piller, S. C., Barker, J. L., Pan, G., Hunter, E., \& McDonald, J. M. (2006). Point mutations in the C-terminus of HIV-1 gp160 reduce apoptosis and calmodulin binding without affecting viral replication. Virology, 344(2), 468-479.

Micoli, K. J., Pan, G., Wu, Y., Williams, J. P., Cook, W. J., \& McDonald, J. M. (2000). Requirement of calmodulin binding by HIV-1 gp160 for enhanced FAS-mediated apoptosis. J Biol Chem, 275(2), 1233-1240.

Miller, M. D., Margot, N., Lu, B., Zhong, L., Chen, S. S., Cheng, A., \& Wulfsohn, M. (2004). Genotypic and phenotypic predictors of the magnitude of response to tenofovir disoproxil fumarate treatment in antiretroviral-experienced patients. J Infect Dis, 189(5), 837-846.

Mink, M., Mosier, S. M., Janumpalli, S., Davison, D., Jin, L., Melby, T., Sista, P., Erickson, J., Lambert, D., Stanfield-Oakley, S. A., Salgo, M., Cammack, N., Matthews, T., \& 
Greenberg, M. L. (2005). Impact of human immunodeficiency virus type 1 gp41 amino acid substitutions selected during enfuvirtide treatment on gp41 binding and antiviral potency of enfuvirtide in vitro. J Virol, 79(19), 12447-12454.

Molina, J. M., Marcelin, A. G., Pavie, J., Heripret, L., De Boever, C. M., Troccaz, M., Leleu, G., \& Calvez, V. (2005). Didanosine in HIV-1-infected patients experiencing failure of antiretroviral therapy: a randomized placebo-controlled trial. J Infect Dis, 191(6), 840-847.

Moncunill, G., Armand-Ugon, M., Pauls, E., Clotet, B., \& Este, J. A. (2008). HIV-1 escape to CCR5 coreceptor antagonism through selection of CXCR4-using variants in vitro. Aids, 22(1), 23-31.

Montefiori, D. C., Pantaleo, G., Fink, L. M., Zhou, J. T., Zhou, J. Y., Bilska, M., Miralles, G. D., \& Fauci, A. S. (1996). Neutralizing and infection-enhancing antibody responses to human immunodeficiency virus type 1 in long-term nonprogressors. J Infect Dis, 173(1), 60-67.

Moog, C., Fleury, H. J., Pellegrin, I., Kirn, A., \& Aubertin, A. M. (1997). Autologous and heterologous neutralizing antibody responses following initial seroconversion in human immunodeficiency virus type 1-infected individuals. J Virol, 71(5), 3734-3741.

Moore, J. P., \& Ho, D. D. (1995). HIV-1 neutralization: the consequences of viral adaptation to growth on transformed T cells. Aids, 9(Suppl A), S117-136.

Moore, J. P., \& Sodroski, J. (1996). Antibody cross-competition analysis of the human immunodeficiency virus type 1 gp120 exterior envelope glycoprotein. J Virol, 70(3), 1863-1872.

Mouscadet, J. F., Arora, R., Andre, J., Lambry, J. C., Delelis, O., Malet, I., Marcelin, A. G., Calvez, V., \& Tchertanov, L. (2009). HIV-1 IN alternative molecular recognition of DNA induced by raltegravir resistance mutations. J Mol Recognit, 22(6), 480-494.

Moyle, G. J., DeJesus, E., Cahn, P., Castillo, S. A., Zhao, H., Gordon, D. N., Craig, C., \& Scott, T. R. (2005). Abacavir once or twice daily combined with once-daily lamivudine and efavirenz for the treatment of antiretroviral-naive HIV-infected adults: results of the Ziagen Once Daily in Antiretroviral Combination Study. J Acquir Immune Defic Syndr, 38(4), 417-425.

Muster, T., Guinea, R., Trkola, A., Purtscher, M., Klima, A., Steindl, F., Palese, P., \& Katinger, H. (1994). Cross-neutralizing activity against divergent human immunodeficiency virus type 1 isolates induced by the gp41 sequence ELDKWAS. J Virol, 68(6), 40314034.

Muster, T., Steindl, F., Purtscher, M., Trkola, A., Klima, A., Himmler, G., Ruker, F., \& Katinger, H. (1993). A conserved neutralizing epitope on gp41 of human immunodeficiency virus type 1. J Virol, 67(11), 6642-6647.

Nakamura, K. J., Gach, J. S., Jones, L., Semrau, K., Walter, J., Bibollet-Ruche, F., Decker, J. M., Heath, L., Decker, W. D., Sinkala, M., Kankasa, C., Thea, D., Mullins, J., Kuhn, L., Zwick, M. B., \& Aldrovandi, G. M. (2011). 4E10-resistant HIV-1 isolated from four subjects with rare membrane-proximal external region polymorphisms. PLoS One, 5(3), e9786.

Nijhuis, M., Schuurman, R., de Jong, D., Erickson, J., Gustchina, E., Albert, J., Schipper, P., Gulnik, S., \& Boucher, C. A. (1999). Increased fitness of drug resistant HIV-1 protease as a result of acquisition of compensatory mutations during suboptimal therapy. Aids, 13(17), 2349-2359.

Nobile, V., Russo, N., Hu, G., \& Riordan, J. F. (1998). Inhibition of human angiogenin by DNA aptamers: nuclear colocalization of an angiogenin-inhibitor complex. Biochemistry, 37(19), 6857-6863. 
O'Brien, T. R., Winkler, C., Dean, M., Nelson, J. A., Carrington, M., Michael, N. L., \& White, G. C., 2nd (1997). HIV-1 infection in a man homozygous for CCR5 delta 32 [letter] [see comments]. Lancet, 349(9060), 1219.

Pancera, M., McLellan, J. S., Wu, X., Zhu, J., Changela, A., Schmidt, S. D., Yang, Y., Zhou, T., Phogat, S., Mascola, J. R., \& Kwong, P. D. (2010). Crystal structure of PG16 and chimeric dissection with somatically related PG9: structure-function analysis of two quaternary-specific antibodies that effectively neutralize HIV-1. J Virol, 84(16), 8098-8110.

Park, E. J., Vujcic, L. K., Anand, R., Theodore, T. S., \& Quinnan, G. V., Jr. (1998). Mutations in both gp120 and gp41 are responsible for the broad neutralization resistance of variant human immunodeficiency virus type $1 \mathrm{MN}$ to antibodies directed at $\mathrm{V} 3$ and non-V3 epitopes. J Virol, 72(9), 7099-7107.

Parkin, N. T., Chappey, C., \& Petropoulos, C. J. (2003). Improving lopinavir genotype algorithm through phenotype correlations: novel mutation patterns and amprenavir cross-resistance. Aids, 17(7), 955-961.

Pastore, C., Nedellec, R., Ramos, A., Hartley, O., Miamidian, J. L., Reeves, J. D., \& Mosier, D. E. (2007). Conserved changes in envelope function during human immunodeficiency virus type 1 coreceptor switching. J Virol, 81(15), 8165-8179.

Pastore, C., Nedellec, R., Ramos, A., Pontow, S., Ratner, L., \& Mosier, D. E. (2006). Human immunodeficiency virus type 1 coreceptor switching: V1/V2 gain-of-fitness mutations compensate for V3 loss-of-fitness mutations. J Virol, 80(2), 750-758.

Patick, A. K., Mo, H., Markowitz, M., Appelt, K., Wu, B., Musick, L., Kalish, V., Kaldor, S., Reich, S., Ho, D., \& Webber, S. (1996). Antiviral and resistance studies of AG1343, an orally bioavailable inhibitor of human immunodeficiency virus protease. Antimicrob Agents Chemother, 40(2), 292-297.

Pellegrin, I., Breilh, D., Coureau, G., Boucher, S., Neau, D., Merel, P., Lacoste, D., Fleury, H., Saux, M. C., Pellegrin, J. L., Lazaro, E., Dabis, F., \& Thiebaut, R. (2007). Interpretation of genotype and pharmacokinetics for resistance to fosamprenavirritonavir-based regimens in antiretroviral-experienced patients. Antimicrob Agents Chemother, 51(4), 1473-1480.

Pellegrin, I., Breilh, D., Ragnaud, J. M., Boucher, S., Neau, D., Fleury, H., Schrive, M. H., Saux, M. C., Pellegrin, J. L., Lazaro, E., \& Vray, M. (2006). Virological responses to atazanavir-ritonavir-based regimens: resistance-substitutions score and pharmacokinetic parameters (Reyaphar study). Antivir Ther, 11(4), 421-429.

Perno, C. F., Cozzi-Lepri, A., Balotta, C., Forbici, F., Violin, M., Bertoli, A., Facchi, G., Pezzotti, P., Cadeo, G., Tositti, G., Pasquinucci, S., Pauluzzi, S., Scalzini, A., Salassa, B., Vincenti, A., Phillips, A. N., Dianzani, F., Appice, A., Angarano, G., Monno, L., Ippolito, G., Moroni, M., \& d' Arminio Monforte, A. (2001). Secondary mutations in the protease region of human immunodeficiency virus and virologic failure in drug-naive patients treated with protease inhibitor-based therapy. I Infect Dis, 184(8), 983-991.

Perno, C. F., Cozzi-Lepri, A., Forbici, F., Bertoli, A., Violin, M., Stella Mura, M., Cadeo, G., Orani, A., Chirianni, A., De Stefano, C., Balotta, C., \& d'Arminio Monforte, A. (2004). Minor mutations in HIV protease at baseline and appearance of primary mutation $90 \mathrm{M}$ in patients for whom their first protease-inhibitor antiretroviral regimens failed. J Infect Dis, 189(11), 1983-1987.

Petropoulos, C. J., Parkin, N. T., Limoli, K. L., Lie, Y. S., Wrin, T., Huang, W., Tian, H., Smith, D., Winslow, G. A., Capon, D. J., \& Whitcomb, J. M. (2000). A novel 
phenotypic drug susceptibility assay for human immunodeficiency virus type 1 . Antimicrob Agents Chemother, 44(4), 920-928.

Platt, E. J., Kuhmann, S. E., Rose, P. P., \& Kabat, D. (2001). Adaptive mutations in the V3 loop of gp120 enhance fusogenicity of human immunodeficiency virus type 1 and enable use of a CCR5 coreceptor that lacks the amino-terminal sulfated region. J Virol, 75(24), 12266-12278.

Platt, E. J., Shea, D. M., Rose, P. P., \& Kabat, D. (2005). Variants of human immunodeficiency virus type 1 that efficiently use CCR5 lacking the tyrosine-sulfated amino terminus have adaptive mutations in gp120, including loss of a functional N-glycan. J Virol, 79(7), 4357-4368.

Poignard, P., Klasse, P. J., \& Sattentau, Q. J. (1996). Antibody neutralization of HIV-1. Immunol Today, 17(5), 239-246.

Pommier, Y., Johnson, A. A., \& Marchand, C. (2005). Integrase inhibitors to treat HIV/AIDS. Nat Rev Drug Discov, 4(3), 236-248.

Posner, M. R., Hideshima, T., Cannon, T., Mukherjee, M., Mayer, K. H., \& Byrn, R. A. (1991). An IgG human monoclonal antibody that reacts with HIV-1/GP120, inhibits virus binding to cells, and neutralizes infection. J Immunol, 146(12), 4325-4332.

Rana, S., Besson, G., Cook, D. G., Rucker, J., Smyth, R. J., Yi, Y., Turner, J. D., Guo, H. H., Du, J. G., Peiper, S. C., Lavi, E., Samson, M., Libert, F., Liesnard, C., Vassart, G., Doms, R. W., Parmentier, M., \& Collman, R. G. (1997). Role of CCR5 in infection of primary macrophages and lymphocytes by macrophage-tropic strains of human immunodeficiency virus: resistance to patient-derived and prototype isolates resulting from the delta ccr5 mutation. J Virol, 71(4), 3219-3227.

Reeves, J. D., Lee, F. H., Miamidian, J. L., Jabara, C. B., Juntilla, M. M., \& Doms, R. W. (2005). Enfuvirtide resistance mutations: impact on human immunodeficiency virus envelope function, entry inhibitor sensitivity, and virus neutralization. J Virol, 79(8), 4991-4999.

Reitz, M. S., Jr., Wilson, C., Naugle, C., Gallo, R. C., \& Robert-Guroff, M. (1988). Generation of a neutralization-resistant variant of HIV-1 is due to selection for a point mutation in the envelope gene. Cell, 54(1), 57-63.

Ren, J., Chamberlain, P. P., Stamp, A., Short, S. A., Weaver, K. L., Romines, K. R., Hazen, R., Freeman, A., Ferris, R. G., Andrews, C. W., Boone, L., Chan, J. H., \& Stammers, D. K. (2008). Structural basis for the improved drug resistance profile of new generation benzophenone non-nucleoside HIV-1 reverse transcriptase inhibitors. J Med Chem, 51(16), 5000-5008.

Ren, J., Esnouf, R., Garman, E., Somers, D., Ross, C., Kirby, I., Keeling, J., Darby, G., Jones, Y., Stuart, D., \& et al. (1995a). High resolution structures of HIV-1 RT from four RTinhibitor complexes. Nat Struct Biol, 2(4), 293-302.

Ren, J., Esnouf, R., Hopkins, A., Ross, C., Jones, Y., Stammers, D., \& Stuart, D. (1995b). The structure of HIV-1 reverse transcriptase complexed with 9-chloro-TIBO: lessons for inhibitor design. Structure, 3(9), 915-926.

Ren, J., Nichols, C., Bird, L., Chamberlain, P., Weaver, K., Short, S., Stuart, D. I., \& Stammers, D. K. (2001). Structural mechanisms of drug resistance for mutations at codons 181 and 188 in HIV-1 reverse transcriptase and the improved resilience of second generation non-nucleoside inhibitors. J Mol Biol, 312(4), 795-805.

Ren, J., Nichols, C. E., Chamberlain, P. P., Weaver, K. L., Short, S. A., Chan, J. H., Kleim, J. P., \& Stammers, D. K. (2007). Relationship of potency and resilience to drug resistant mutations for GW420867X revealed by crystal structures of inhibitor complexes for 
wild-type, Leu100Ile, Lys101Glu, and Tyr188Cys mutant HIV-1 reverse transcriptases. J Med Chem, 50(10), 2301-2309.

Ren, J., Nichols, C. E., Chamberlain, P. P., Weaver, K. L., Short, S. A., \& Stammers, D. K. (2004). Crystal structures of HIV-1 reverse transcriptases mutated at codons 100, 106 and 108 and mechanisms of resistance to non-nucleoside inhibitors. J Mol Biol, 336(3), 569-578.

Ren, J., \& Stammers, D. K. (2008). Structural basis for drug resistance mechanisms for nonnucleoside inhibitors of HIV reverse transcriptase. Virus Res, 134(1-2), 157-170.

Rey, D., Hoen, B., Chavanet, P., Schmitt, M. P., Hoizey, G., Meyer, P., Peytavin, G., Spire, B., Allavena, C., Diemer, M., May, T., Schmit, J. L., Duong, M., Calvez, V., \& Lang, J. M. (2009). High rate of early virological failure with the once-daily tenofovir/lamivudine/nevirapine combination in naive HIV-1-infected patients. J Antimicrob Chemother, 63(2), 380-388.

Rhee, S. Y., Fessel, W. J., Zolopa, A. R., Hurley, L., Liu, T., Taylor, J., Nguyen, D. P., Slome, S., Klein, D., Horberg, M., Flamm, J., Follansbee, S., Schapiro, J. M., \& Shafer, R. W. (2005). HIV-1 Protease and reverse-transcriptase mutations: correlations with antiretroviral therapy in subtype B isolates and implications for drug-resistance surveillance. J Infect Dis, 192(3), 456-465.

Rhee, S. Y., Gonzales, M. J., Kantor, R., Betts, B. J., Ravela, J., \& Shafer, R. W. (2003). Human immunodeficiency virus reverse transcriptase and protease sequence database. Nucleic Acids Res, 31(1), 298-303.

Rhee, S. Y., Kantor, R., Katzenstein, D. A., Camacho, R., Morris, L., Sirivichayakul, S., Jorgensen, L., Brigido, L. F., Schapiro, J. M., \& Shafer, R. W. (2006a). HIV-1 pol mutation frequency by subtype and treatment experience: extension of the HIVseq program to seven non-B subtypes. Aids, 20(5), 643-651.

Rhee, S. Y., Liu, T., Ravela, J., Gonzales, M. J., \& Shafer, R. W. (2004). Distribution of human immunodeficiency virus type 1 protease and reverse transcriptase mutation patterns in 4,183 persons undergoing genotypic resistance testing. Antimicrob Agents Chemother, 48(8), 3122-3126.

Rhee, S. Y., Liu, T. F., Holmes, S. P., \& Shafer, R. W. (2007). HIV-1 subtype B protease and reverse transcriptase amino acid covariation. PLoS Comput Biol, 3(5), e87.

Rhee, S. Y., Taylor, J., Wadhera, G., Ben-Hur, A., Brutlag, D. L., \& Shafer, R. W. (2006b). Genotypic predictors of human immunodeficiency virus type 1 drug resistance. Proc Natl Acad Sci U S A, 103(46), 17355-17360.

Roge, B. T., Katzenstein, T. L., Obel, N., Nielsen, H., Kirk, O., Pedersen, C., Mathiesen, L., Lundgren, J., \& Gerstoft, J. (2003). K65R with and without S68: a new resistance profile in vivo detected in most patients failing abacavir, didanosine and stavudine. Antivir Ther, 8(2), 173-182.

Ross, L., Scarsella, A., Raffanti, S., Henry, K., Becker, S., Fisher, R., Liao, Q., Hirani, A., Graham, N., St Clair, M., \& Hernandez, J. (2001). Thymidine analog and multinucleoside resistance mutations are associated with decreased phenotypic susceptibility to stavudine in HIV type 1 isolated from zidovudine-naive patients experiencing viremia on stavudine-containing regimens. AIDS Res Hum Retroviruses, 17(12), 1107-1115.

Ruckman, J., Green, L. S., Beeson, J., Waugh, S., Gillette, W. L., Henninger, D. D., ClaessonWelsh, L., \& Janjic, N. (1998). 2'-Fluoropyrimidine RNA-based aptamers to the 165amino acid form of vascular endothelial growth factor (VEGF165). Inhibition of receptor binding and VEGF-induced vascular permeability through interactions requiring the exon 7-encoded domain. J Biol Chem, 273(32), 20556-20567. 
Ruprecht, C. R., Krarup, A., Reynell, L., Mann, A. M., Brandenberg, O. F., Berlinger, L., Abela, I. A., Regoes, R. R., Gunthard, H. F., Rusert, P., \& Trkola, A. (2011). MPERspecific antibodies induce gp120 shedding and irreversibly neutralize HIV-1. J Exp Med, 208(3), 439-454.

Rusconi, C. P., Roberts, J. D., Pitoc, G. A., Nimjee, S. M., White, R. R., Quick, G., Jr., Scardino, E., Fay, W. P., \& Sullenger, B. A. (2004). Antidote-mediated control of an anticoagulant aptamer in vivo. Nat Biotechnol, 22(11), 1423-1428.

Rusconi, C. P., Scardino, E., Layzer, J., Pitoc, G. A., Ortel, T. L., Monroe, D., \& Sullenger, B. A. (2002). RNA aptamers as reversible antagonists of coagulation factor IXa. Nature, 419(6902), 90-94.

Samson, M., Libert, F., Doranz, B. J., Rucker, J., Liesnard, C., Farber, C. M., Saragosti, S., Lapoumeroulie, C., Cognaux, J., Forceille, C., Muyldermans, G., Verhofstede, C., Burtonboy, G., Georges, M., Imai, T., Rana, S., Yi, Y., Smyth, R. J., Collman, R. G., Doms, R. W., Vassart, G., \& Parmentier, M. (1996). Resistance to HIV-1 infection in caucasian individuals bearing mutant alleles of the CCR-5 chemokine receptor gene [see comments]. Nature, 382(6593), 722-725.

Sarafianos, S. G., Das, K., Clark, A. D., Jr., Ding, J., Boyer, P. L., Hughes, S. H., \& Arnold, E. (1999). Lamivudine (3TC) resistance in HIV-1 reverse transcriptase involves steric hindrance with beta-branched amino acids. Proc Natl Acad Sci U S A, 96(18), 1002710032.

Sarafianos, S. G., Das, K., Hughes, S. H., \& Arnold, E. (2004). Taking aim at a moving target: designing drugs to inhibit drug-resistant HIV-1 reverse transcriptases. Curr Opin Struct Biol, 14(6), 716-730.

Sarafianos, S. G., Marchand, B., Das, K., Himmel, D. M., Parniak, M. A., Hughes, S. H., \& Arnold, E. (2009). Structure and function of HIV-1 reverse transcriptase: molecular mechanisms of polymerization and inhibition. J Mol Biol, 385(3), 693-713.

Sattentau, Q. J., \& Moore, J. P. (1995). Human immunodeficiency virus type 1 neutralization is determined by epitope exposure on the gp120 oligomer. J Exp Med, 182(1), 185-196.

Scanlan, C. N., Pantophlet, R., Wormald, M. R., Saphire, E. O., Calarese, D., Stanfield, R., Wilson, I. A., Katinger, H., Dwek, R. A., Burton, D. R., \& Rudd, P. M. (2003). The carbohydrate epitope of the neutralizing anti-HIV-1 antibody 2G12. Adv Exp Med Biol, 535, 205-218.

Seclen, E., Gonzalez Mdel, M., Lapaz, M., Rodriguez, C., del Romero, J., Aguilera, A., de Mendoza, C., Soriano, V., \& Poveda, E. (2011). Primary resistance to maraviroc in a large set of R5-V3 viral sequences from HIV-1-infected patients. J Antimicrob Chemother, 65(12), 2502-2504.

Shafer, R. W., \& Schapiro, J. M. (2008). HIV-1 drug resistance mutations: an updated framework for the second decade of HAART. AIDS Rev, 10(2), 67-84.

Shimura, K., Kodama, E., Sakagami, Y., Matsuzaki, Y., Watanabe, W., Yamataka, K., Watanabe, Y., Ohata, Y., Doi, S., Sato, M., Kano, M., Ikeda, S., \& Matsuoka, M. (2008). Broad antiretroviral activity and resistance profile of the novel human immunodeficiency virus integrase inhibitor elvitegravir (JTK-303/GS-9137). J Virol, 82(2), 764-774.

Shulman, N. S., Bosch, R. J., Mellors, J. W., Albrecht, M. A., \& Katzenstein, D. A. (2004). Genetic correlates of efavirenz hypersusceptibility. Aids, 18(13), 1781-1785.

Shulman, N. S., Zolopa, A. R., Passaro, D. J., Murlidharan, U., Israelski, D. M., Brosgart, C. L., Miller, M. D., Van Doren, S., Shafer, R. W., \& Katzenstein, D. A. (2000). Efavirenz- and adefovir dipivoxil-based salvage therapy in highly treatment- 
experienced patients: clinical and genotypic predictors of virologic response. J Acquir Immune Defic Syndr, 23(3), 221-226.

Sing, T., Low, A. J., Beerenwinkel, N., Sander, O., Cheung, P. K., Domingues, F. S., Buch, J., Daumer, M., Kaiser, R., Lengauer, T., \& Harrigan, P. R. (2007). Predicting HIV coreceptor usage on the basis of genetic and clinical covariates. Antivir Ther, 12(7), 1097-1106.

Sista, P. R., Melby, T., Davison, D., Jin, L., Mosier, S., Mink, M., Nelson, E. L., DeMasi, R., Cammack, N., Salgo, M. P., Matthews, T. J., \& Greenberg, M. L. (2004). Characterization of determinants of genotypic and phenotypic resistance to enfuvirtide in baseline and on-treatment HIV-1 isolates. Aids, 18(13), 1787-1794.

Smith, K. Y., Weinberg, W. G., Dejesus, E., Fischl, M. A., Liao, Q., Ross, L. L., Pakes, G. E., Pappa, K. A., \& Lancaster, C. T. (2008). Fosamprenavir or atazanavir once daily boosted with ritonavir $100 \mathrm{mg}$, plus tenofovir/emtricitabine, for the initial treatment of HIV infection: 48-week results of ALERT. AIDS Res Ther, 5, 5.

Sosa, N., Hill-Zabala, C., Dejesus, E., Herrera, G., Florance, A., Watson, M., Vavro, C., \& Shaefer, M. (2005). Abacavir and lamivudine fixed-dose combination tablet once daily compared with abacavir and lamivudine twice daily in HIV-infected patients over 48 weeks (ESS30008, SEAL). J Acquir Immune Defic Syndr, 40(4), 422-427.

Su, C., Melby, T., DeMasi, R., Ravindran, P., \& Heilek-Snyder, G. (2006). Genotypic changes in human immunodeficiency virus type 1 envelope glycoproteins on treatment with the fusion inhibitor enfuvirtide and their influence on changes in drug susceptibility in vitro. J Clin Virol, 36(4), 249-257.

Sugiura, W., Matsuda, Z., Yokomaku, Y., Hertogs, K., Larder, B., Oishi, T., Okano, A., Shiino, T., Tatsumi, M., Matsuda, M., Abumi, H., Takata, N., Shirahata, S., Yamada, K., Yoshikura, H., \& Nagai, Y. (2002). Interference between D30N and L90M in selection and development of protease inhibitor-resistant human immunodeficiency virus type 1. Antimicrob Agents Chemother, 46(3), 708-715.

Svarovskaia, E. S., Margot, N. A., Bae, A. S., Waters, J. M., Goodman, D., Zhong, L., BorrotoEsoda, K., \& Miller, M. D. (2007). Low-level K65R mutation in HIV-1 reverse transcriptase of treatment-experienced patients exposed to abacavir or didanosine. J Acquir Immune Defic Syndr, 46(2), 174-180.

Svicher, V., Balestra, E., Cento, V., Sarmati, L., Dori, L., Vandenbroucke, I., D'Arrigo, R., Buonomini, A. R., Van Marck, H., Surdo, M., Saccomandi, P., Mostmans, W., Aerssens, J., Aquaro, S., Stuyver, L. J., Andreoni, M., Ceccherini-Silberstein, F., \& Perno, C. F. (2011). HIV-1 dual/mixed tropic isolates show different genetic and phenotypic characteristics and response to maraviroc in vitro. Antiviral Res, 90(1), 42-53.

Svicher, V., Ceccherini-Silberstein, F., Erba, F., Santoro, M., Gori, C., Bellocchi, M. C., Giannella, S., Trotta, M. P., Monforte, A., Antinori, A., \& Perno, C. F. (2005). Novel human immunodeficiency virus type 1 protease mutations potentially involved in resistance to protease inhibitors. Antimicrob Agents Chemother, 49(5), 2015-2025.

Thali, M., Moore, J. P., Furman, C., Charles, M., Ho, D. D., Robinson, J., \& Sodroski, J. (1993). Characterization of conserved human immunodeficiency virus type 1 gp120 neutralization epitopes exposed upon gp120-CD4 binding. J Virol, 67(7), 3978-3988.

Theodorou, I., Meyer, L., Magierowska, M., Katlama, C., \& Rouzioux, C. (1997). HIV-1 infection in an individual homozygous for CCR5 delta 32. Seroco Study Group [letter] [see comments]. Lancet, 349(9060), 1219-1220.

Tilton, J. C., Wilen, C. B., Didigu, C. A., Sinha, R., Harrison, J. E., Agrawal-Gamse, C., Henning, E. A., Bushman, F. D., Martin, J. N., Deeks, S. G., \& Doms, R. W. (2011). A 
maraviroc-resistant HIV-1 with narrow cross-resistance to other CCR5 antagonists depends on both N-terminal and extracellular loop domains of drug-bound CCR5. J Virol, 84(20), 10863-10876.

Trkola, A., Dragic, T., Arthos, J., Binley, J. M., Olson, W. C., Allaway, G. P., Cheng-Mayer, C., Robinson, J., Maddon, P. J., \& Moore, J. P. (1996a). CD4-dependent, antibodysensitive interactions between HIV-1 and its co- receptor CCR-5 [see comments]. Nature, 384(6605), 184-187.

Trkola, A., Purtscher, M., Muster, T., Ballaun, C., Buchacher, A., Sullivan, N., Srinivasan, K., Sodroski, J., Moore, J. P., \& Katinger, H. (1996b). Human monoclonal antibody 2G12 defines a distinctive neutralization epitope on the gp120 glycoprotein of human immunodeficiency virus type 1. J Virol, 70(2), 1100-1108.

van Maarseveen, N. M., de Jong, D., Boucher, C. A., \& Nijhuis, M. (2006). An increase in viral replicative capacity drives the evolution of protease inhibitor-resistant human immunodeficiency virus type 1 in the absence of drugs. I Acquir Immune Defic Syndr, 42(2), 162-168.

Vermeiren, H., Van Craenenbroeck, E., Alen, P., Bacheler, L., Picchio, G., \& Lecocq, P. (2007). Prediction of HIV-1 drug susceptibility phenotype from the viral genotype using linear regression modeling. J Virol Methods, 145(1), 47-55.

Vinores, S. A. (2003). Technology evaluation: pegaptanib, Eyetech/Pfizer. Curr Opin Mol Ther, 5(6), 673-679.

Vora, S., Marcelin, A. G., Gunthard, H. F., Flandre, P., Hirsch, H. H., Masquelier, B., Zinkernagel, A., Peytavin, G., Calvez, V., Perrin, L., \& Yerly, S. (2006). Clinical validation of atazanavir/ritonavir genotypic resistance score in protease inhibitorexperienced patients. Aids, 20(1), 35-40.

Vray, M., Meynard, J. L., Dalban, C., Morand-Joubert, L., Clavel, F., Brun-Vezinet, F., Peytavin, G., Costagliola, D., \& Girard, P. M. (2003). Predictors of the virological response to a change in the antiretroviral treatment regimen in HIV-1-infected patients enrolled in a randomized trial comparing genotyping, phenotyping and standard of care (Narval trial, ANRS 088). Antivir Ther, 8(5), 427-434.

Walker, L. M., Phogat, S. K., Chan-Hui, P. Y., Wagner, D., Phung, P., Goss, J. L., Wrin, T., Simek, M. D., Fling, S., Mitcham, J. L., Lehrman, J. K., Priddy, F. H., Olsen, O. A., Frey, S. M., Hammond, P. W., Kaminsky, S., Zamb, T., Moyle, M., Koff, W. C., Poignard, P., \& Burton, D. R. (2009). Broad and potent neutralizing antibodies from an African donor reveal a new HIV-1 vaccine target. Science, 326(5950), 285-289.

Walmsley, S. L., Kelly, D. V., Tseng, A. L., Humar, A., \& Harrigan, P. R. (2001). Nonnucleoside reverse transcriptase inhibitor failure impairs HIV-RNA responses to efavirenz-containing salvage antiretroviral therapy. Aids, 15(12), 1581-1584.

Wang, J., Tong, P., Lu, L., Zhou, L., Xu, L., Jiang, S., \& Chen, Y. H. (2011). HIV-1 gp41 core with exposed membrane-proximal external region inducing broad HIV-1 neutralizing antibodies. PLoS One, 6(3), e18233.

Wang, Z., Lee, B., Murray, J. L., Bonneau, F., Sun, Y., Schweickart, V., Zhang, T., \& Peiper, S. C. (1999). CCR5 HIV-1 coreceptor activity. Role of cooperativity between residues in Nterminal extracellular and intracellular domains. J Biol Chem, 274(40), 28413-28419.

Watts, J. M., Dang, K. K., Gorelick, R. J., Leonard, C. W., Bess, J. W., Jr., Swanstrom, R., Burch, C. L., \& Weeks, K. M. (2009). Architecture and secondary structure of an entire HIV-1 RNA genome. Nature, 460(7256), 711-716.

Westby, M., Smith-Burchnell, C., Mori, J., Lewis, M., Mosley, M., Stockdale, M., Dorr, P., Ciaramella, G., \& Perros, M. (2007). Reduced maximal inhibition in phenotypic 
susceptibility assays indicates that viral strains resistant to the CCR5 antagonist maraviroc utilize inhibitor-bound receptor for entry. J Virol, 81(5), 2359-2371.

Whitcomb, J. M., Parkin, N. T., Chappey, C., Hellmann, N. S., \& Petropoulos, C. J. (2003). Broad nucleoside reverse-transcriptase inhibitor cross-resistance in human immunodeficiency virus type 1 clinical isolates. J Infect Dis, 188(7), 992-1000.

White, R. R., Shan, S., Rusconi, C. P., Shetty, G., Dewhirst, M. W., Kontos, C. D., \& Sullenger, B. A. (2003). Inhibition of rat corneal angiogenesis by a nuclease-resistant RNA aptamer specific for angiopoietin-2. Proc Natl Acad Sci U S A, 100(9), 5028-5033.

Wild, C. T., Shugars, D. C., Greenwell, T. K., McDanal, C. B., \& Matthews, T. J. (1994). Peptides corresponding to a predictive alpha-helical domain of human immunodeficiency virus type 1 gp41 are potent inhibitors of virus infection. Proc Natl Acad Sci U S A, 91(21), 9770-9774.

Winters, B., Montaner, J., Harrigan, P. R., Gazzard, B., Pozniak, A., Miller, M. D., Emery, S., van Leth, F., Robinson, P., Baxter, J. D., Perez-Elias, M., Castor, D., Hammer, S., Rinehart, A., Vermeiren, H., Van Craenenbroeck, E., \& Bacheler, L. (2008). Determination of clinically relevant cutoffs for HIV-1 phenotypic resistance estimates through a combined analysis of clinical trial and cohort data. J Acquir Immune Defic Syndr, 48(1), 26-34.

Winters, M. A., Bosch, R. J., Albrecht, M. A., \& Katzenstein, D. A. (2003). Clinical impact of the $\mathrm{M} 184 \mathrm{~V}$ mutation on switching to didanosine or maintaining lamivudine treatment in nucleoside reverse-transcriptase inhibitor-experienced patients. J Infect Dis, 188(4), 537-540.

Winters, M. A., Shafer, R. W., Jellinger, R. A., Mamtora, G., Gingeras, T., \& Merigan, T. C. (1997). Human immunodeficiency virus type 1 reverse transcriptase genotype and drug susceptibility changes in infected individuals receiving dideoxyinosine monotherapy for 1 to 2 years. Antimicrob Agents Chemother, 41(4), 757-762.

Wu, L., Gerard, N. P., Wyatt, R., Choe, H., Parolin, C., Ruffing, N., Borsetti, A., Cardoso, A. A., Desjardin, E., Newman, W., Gerard, C., \& Sodroski, J. (1996). CD4-induced interaction of primary HIV-1 gp120 glycoproteins with the chemokine receptor CCR-5 [see comments]. Nature, 384(6605), 179-183.

Wu, T. D., Schiffer, C. A., Gonzales, M. J., Taylor, J., Kantor, R., Chou, S., Israelski, D., Zolopa, A. R., Fessel, W. J., \& Shafer, R. W. (2003). Mutation patterns and structural correlates in human immunodeficiency virus type 1 protease following different protease inhibitor treatments. J Virol, 77(8), 4836-4847.

Wu, X., Yang, Z. Y., Li, Y., Hogerkorp, C. M., Schief, W. R., Seaman, M. S., Zhou, T., Schmidt, S. D., Wu, L., Xu, L., Longo, N. S., McKee, K., O'Dell, S., Louder, M. K., Wycuff, D. L., Feng, Y., Nason, M., Doria-Rose, N., Connors, M., Kwong, P. D., Roederer, M., Wyatt, R. T., Nabel, G. J., \& Mascola, J. R. (2010). Rational design of envelope identifies broadly neutralizing human monoclonal antibodies to HIV-1. Science, 329(5993), 856-861.

Wyatt, R., Kwong, P. D., Desjardins, E., Sweet, R. W., Robinson, J., Hendrickson, W. A., \& Sodroski, J. G. (1998). The antigenic structure of the HIV gp120 envelope glycoprotein [see comments]. Nature, 393(6686), 705-711.

Xu, L., Pozniak, A., Wildfire, A., Stanfield-Oakley, S. A., Mosier, S. M., Ratcliffe, D., Workman, J., Joall, A., Myers, R., Smit, E., Cane, P. A., Greenberg, M. L., \& Pillay, D. (2005). Emergence and evolution of enfuvirtide resistance following long-term therapy involves heptad repeat 2 mutations within gp41. Antimicrob Agents Chemother, 49(3), 1113-1119. 
Yahi, N., Tamalet, C., Tourres, C., Tivoli, N., Ariasi, F., Volot, F., Gastaut, J. A., Gallais, H., Moreau, J., \& Fantini, J. (1999). Mutation patterns of the reverse transcriptase and protease genes in human immunodeficiency virus type 1-infected patients undergoing combination therapy: survey of 787 sequences. J Clin Microbiol, 37(12), 4099-4106.

Yahi, N., Tamalet, C., Tourres, C., Tivoli, N., \& Fantini, J. (2000). Mutation L210W of HIV-1 reverse transcriptase in patients receiving combination therapy. Incidence, association with other mutations, and effects on the structure of mutated reverse transcriptase. J Biomed Sci, 7(6), 507-513.

Yuan, Y., Maeda, Y., Terasawa, H., Monde, K., Harada, S., \& Yusa, K. (2011). A combination of polymorphic mutations in V3 loop of HIV-1 gp120 can confer noncompetitive resistance to maraviroc. Virology, 413(2), 293-299.

Zhou, T., Georgiev, I., Wu, X., Yang, Z. Y., Dai, K., Finzi, A., Kwon, Y. D., Scheid, J. F., Shi, W., Xu, L., Yang, Y., Zhu, J., Nussenzweig, M. C., Sodroski, J., Shapiro, L., Nabel, G. J., Mascola, J. R., \& Kwong, P. D. (2011). Structural basis for broad and potent neutralization of HIV-1 by antibody VRC01. Science, 329(5993), 811-817.

Zhu, D. M., Shi, J., Liu, S., Liu, Y., \& Zheng, D. (2011). HIV infection enhances TRAILinduced cell death in macrophage by down-regulating decoy receptor expression and generation of reactive oxygen species. PLoS One, 6(4), e18291.

Zimmerman, P. A., Buckler-White, A., Alkhatib, G., Spalding, T., Kubofcik, J., Combadiere, C., Weissman, D., Cohen, O., Rubbert, A., Lam, G., Vaccarezza, M., Kennedy, P. E., Kumaraswami, V., Giorgi, J. V., Detels, R., Hunter, J., Chopek, M., Berger, E. A., Fauci, A. S., Nutman, T. B., \& Murphy, P. M. (1997). Inherited resistance to HIV-1 conferred by an inactivating mutation in CC chemokine receptor 5: studies in populations with contrasting clinical phenotypes, defined racial background, and quantified risk. Mol Med, 3(1), 23-36.

Zolopa, A. R., Shafer, R. W., Warford, A., Montoya, J. G., Hsu, P., Katzenstein, D., Merigan, T. C., \& Efron, B. (1999). HIV-1 genotypic resistance patterns predict response to saquinavir-ritonavir therapy in patients in whom previous protease inhibitor therapy had failed. Ann Intern Med, 131(11), 813-821.

Zwick, M. B., Jensen, R., Church, S., Wang, M., Stiegler, G., Kunert, R., Katinger, H., \& Burton, D. R. (2005). Anti-human immunodeficiency virus type 1 (HIV-1) antibodies 2F5 and 4 E10 require surprisingly few crucial residues in the membrane-proximal external region of glycoprotein gp41 to neutralize HIV-1. J Virol, 79(2), 1252-1261.

Zwick, M. B., Labrijn, A. F., Wang, M., Spenlehauer, C., Saphire, E. O., Binley, J. M., Moore, J. P., Stiegler, G., Katinger, H., Burton, D. R., \& Parren, P. W. (2001). Broadly neutralizing antibodies targeted to the membrane-proximal external region of human immunodeficiency virus type 1 glycoprotein gp41. J Virol, 75(22), 10892-10905. 


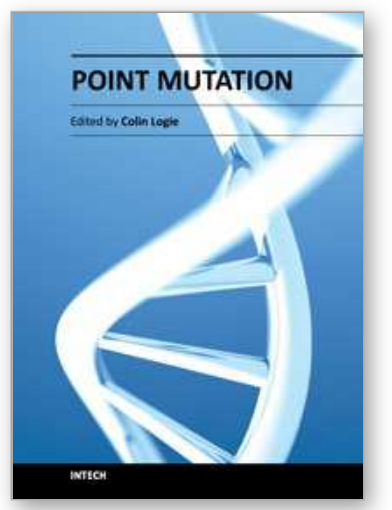

\author{
Point Mutation \\ Edited by Dr Colin Logie
}

ISBN 978-953-51-0331-8

Hard cover, 352 pages

Publisher InTech

Published online 21, March, 2012

Published in print edition March, 2012

This book concerns the signatures left behind in chromosomes by the forces that drive DNA code evolution in the form of DNA nucleotide substitutions. Since the genetic code predetermines the molecular basis of life, it could have been about any aspect of biology. As it happens, it is largely about recent adaptation of pathogens and their human host. Nine chapters are medically oriented, two are bioinformatics-oriented and one is technological, describing the state of the art in synthetic point mutagenesis. What stands out in this book is the increasing rate at which DNA data has been amassed in the course of the past decade and how knowledge in this vibrant research field is currently being translated in the medical world.

\title{
How to reference
}

In order to correctly reference this scholarly work, feel free to copy and paste the following:

Makobetsa Khati and Laura Millroy (2012). Point Mutations Associated with HIV-1 Drug Resistance, Evasion of the Immune Response and AIDS Pathogenesis, Point Mutation, Dr Colin Logie (Ed.), ISBN: 978-953-51-03318, InTech, Available from: http://www.intechopen.com/books/point-mutation/point-mutations-associated-withhiv-1-drug-resistance-evasion-of-the-immune-response-and-aids-pathog

\section{INTECH}

open science | open minds

\section{InTech Europe}

University Campus STeP Ri Slavka Krautzeka 83/A 51000 Rijeka, Croatia Phone: +385 (51) 770447 Fax: +385 (51) 686166 www.intechopen.com

\section{InTech China}

Unit 405, Office Block, Hotel Equatorial Shanghai No.65, Yan An Road (West), Shanghai, 200040, China 中国上海市延安西路65号上海国际贵都大饭店办公楼405单元 Phone: +86-21-62489820

Fax: +86-21-62489821 
(C) 2012 The Author(s). Licensee IntechOpen. This is an open access article distributed under the terms of the Creative Commons Attribution 3.0 License, which permits unrestricted use, distribution, and reproduction in any medium, provided the original work is properly cited. 